NBER WORKING PAPER SERIES

\title{
THE EFFECTS OF GUN PREVALENCE ON BURGLARY: DETERRENCE VS INDUCEMENT
}

\author{
Philip J. Cook \\ Jens Ludwig \\ Working Paper 8926 \\ http://www.nber.org/papers/w8926
NATIONAL BUREAU OF ECONOMIC RESEARCH
1050 Massachusetts Avenue
Cambridge, MA 02138
May 2002

This paper was supported in part by a grant from the Joyce Foundation. Thanks to Marjorie Cohen, Brian Deer, Zac Hudson, Sinead Keegan, Josh Pinkston, Justin Treloar, Eric Younger and especially Bob Malme for excellent research assistance, to the Prince Georges County Police Department, Stacy Dickert-Conlin, Mark Duggan, Pat Mayhew (and others at the British Crime Survey), Robert Moffitt and Steve Raphael for data, and to Ed Glaeser, David Kopel, Arik Levinson, Bruce Sacerdote and seminar participants at the National Bureau of Economic Research, University of Maryland, William and Mary and the Brookings Institute gun conference for helpful comments. The research in this paper was conducted while the authors were Census Bureau research associates at the Triangle Census Research Data Center. Research results and conclusions are those of the authors and do not necessarily indicate concurrence by the Bureau of the Census. This paper has been screened to insure that no confidential data are revealed. We thank Alison Hagy and Michelle Danis for their guidance at the Center. The views expressed herein are those of the authors and not necessarily those of the National Bureau of Economic Research.

(C) 2002 by Philip J. Cook and Jens Ludwig. All rights reserved. Short sections of text, not to exceed two paragraphs, may be quoted without explicit permission provided that full credit, including (C) notice, is given to the source. 
The Effects of Gun Prevalence on Burglary: Deterrence vs Inducement

Philip J. Cook and Jens Ludwig

NBER Working Paper No. 8926

May 2002

JEL No. K42

\begin{abstract}
The proposition that widespread gun ownership serves as a deterrent to residential burglary is widely touted by advocates, but the evidence is weak, consisting of anecdotes, interviews with burglars, casual comparisons with other countries, and the like. A more systematic exploration requires data on local rates of gun ownership and of residential burglary, and such data have only recently become available. In this paper we exploit a new well-validated proxy for local gun-ownership prevalence - the proportion of suicides that involve firearms - together with newly available geo-coded data from the National Crime Victimization Survey, to produce the first systematic estimates of the net effects of gun prevalence on residential burglary patterns.

The importance of such empirical work stems in part from the fact that theoretical considerations do not provide much guidance in predicting the net effects of widespread gun ownership. Guns in the home may pose a threat to burglars, but also serve as an inducement, since guns are particularly valuable loot. Other things equal, a gun-rich community provides more lucrative burglary opportunities than one where guns are more sparse. The new empirical results reported here provide no support for a net deterrent effect from widespread gun ownership. Rather, our analysis concludes that residential burglary rates tend to increase with community gun prevalence.
\end{abstract}

Philip J. Cook

Sanford Institute for Policy Studies

Box 90245

Duke University

Durham, NC 27708

and NBER

cook@pps.duke.edu
Jens Ludwig

Economic Studies Program

The Brookings Institution

1775 Massachusetts Avenue, NW

Washington, DC 20036

jludwig@brookings.edu 


\section{Introduction}

Compared with other wealthy nations, the United States has a high rate of civilian firearms ownership, with 35-40 percent of all households possessing at least one gun (Smith, 2000). The net effect of widespread gun ownership on the amount and costs of crime remains a contentious issue because guns have virtuous as well as vicious uses: the ready availability of guns may increase gun use by criminal assailants and thereby increase the lethality of assaults and robberies (Zimring, 1968, 1972; Cook, 1987, 1991; Zimring and Hawkins 1997; Duggan, $2001) ;{ }^{1}$ on the other hand, the widespread ownership of guns may increase the likelihood that victims will be able to defend themselves against attack and even inflict injury on would-be assailants, which would tend to deter assaults and reduce the likelihood of victim losses in the event of assault (Kleck 1997; Lott 2000).

The balance between virtuous and vicious uses has traditionally favored keeping a gun at home over carrying one in public, with the latter subject to more stringent regulation. Guns in the home do not threaten the public at large in any direct way, and may enhance the capacity for defending against intruders. Furthermore, armed households arguably provide a deterrent to residential burglary, and particularly to "hot" burglaries of occupied dwellings; if burglars lack "inside" knowledge about which households are armed, this crime-control benefit is not limited to those homes that actually have guns ready at hand, but extends to the entire community (Kopel 2001). Thus there may be a positive externality to keeping a gun at home for self-defense.

While the existence of a burglary-deterrent effect is asserted frequently and with great confidence by advocates, ${ }^{2}$ the empirical support for this assertion is weak. The available evidence consists of anecdotes, interviews with burglars, casual comparisons with other countries, and the like. A more systematic exploration requires data on local rates of gun ownership and of residential burglary, and such data have only recently become available. In this paper we exploit a new well-validated proxy for local gun-ownership prevalence - the proportion of suicides that involve firearms - together with newly available geo-coded data from the National Crime Victimization Survey, to produce the first systematic estimates of the net effects of gun prevalence on residential burglary patterns.

The importance of such empirical work stems in part from the fact that theoretical

${ }^{1}$ In addition to its effects on crime, gun ownership may impose other costs on society as well. It may increase the suicide rate (Miller and Hemenway 1999; Ludwig and Cook 2000; Cutler, Glaeser and Norberg 2001; Wintemute et al. 2001; Duggan 2002) and the rate of unintentional shootings (Miller, Azrael and Hemenway in press). The relative frequency of different circumstances for shootings in residences has been documented in Kellermann and Reay (1986) and Lee et al. (1991).

${ }^{2}$ For some recent assertions on the deterrent effect in the popular press, see, for example, Armstrong (2000), Steyn (2000), Witkin (1994), Tucker (1996), and Rowe (2001). 
considerations do not provide much guidance in predicting the net effects of widespread gun ownership. Guns in the home may pose a threat to burglars, but also serve as an inducement, since guns are particularly valuable loot (Cook, Molliconi, and Cole 1995). Other things equal, a gun-rich community provides more lucrative burglary opportunities than one where guns are more sparse. ${ }^{3}$ The net result for burglary rates and "hot" burglary rates depends in part on the extent to which burglars can discriminate between occupied and unoccupied homes, and on how they assess the relevant risk-reward tradeoff.

The new empirical results reported here provide no support for a net deterrent effect from widespread gun ownership. Indeed, our analysis concludes that residential burglary rates tend to increase with community gun prevalence, while the "hot" proportion of these burglaries is unaffected. The challenge to establishing a causal interpretation to these results comes from the possibility that gun ownership may be both cause and effect of local burglary patterns, or that both variables may be driven by some unmeasured third factor. While there is no entirely persuasive way to rule out such competing explanations, our findings are robust to a variety of empirical approaches.

Our main results come from cross-section regression analysis of National Crime Victimization Survey (NCVS) data augmented by a proxy measure of county-level gun prevalence. In this analysis we control for a long list of household- and county-level attributes, and in one specification allow each state to have a different intercept.

To deal with the potential problem of reverse causation, we replicate our analyses using a 22-year panel of police-reported crime data obtained from the FBI's Uniform Crime Reports (UCR), finding that lagged gun-ownership rates are positively related to future burglary rates. On the other hand lagged burglary rates appear to have a negligible effect on future gun prevalence, at least in the short run. Unfortunately the UCR data do not distinguish between burglaries to occupied versus unoccupied homes, and thus cannot support a separate analysis of hot burglaries.

The issue of reverse causation is also addressed by use of "instrumental variables" (IV) estimates. The specific instrument employed in these estimates is the percentage of the state population living in rural areas in 1950, an indicator of rural tradition in the state to which gun ownership is closely tied. The resulting estimates are compatible with the ordinary-least-squares estimates in suggesting a non-negative relationship between gun density and burglary rates.

The remainder of the paper is organized as follows. The next section offers a brief review of the existing evidence, with a particular focus on international comparisons. The data on burglary and the prevalence of gun ownership are discussed in the third section. The fourth presents results on the relationship between gun prevalence and burglary rates. We develop a

${ }^{3}$ Guns may also be useful inputs into the burglary production process, and may be less costly for criminals to obtain in areas with high levels of gun ownership. 
simple model demonstrating that the theoretical relationship between guns and burglary is indeterminate, and then present new empirical results on this relationship. The fifth section examines the relationship between guns and hot burglary rates, and the final section concludes.

\section{Review of the Existing Evidence}

The evidence typically cited in discussions of how gun prevalence affects residential burglary rates is of five types. First, data on the frequency of gun use by householders against intruders are cited to support the plausibility of a deterrence hypothesis. Second, interviews with burglars or former burglars provide more direct evidence on the deterrent effect, and also on the inducement to burglary of guns in the home. Third, international comparisons are offered, usually comparing the percentage of residential burglaries that are "hot" in the United States with one or more other countries that have lower gun prevalence. Fourth, anecdotes (sometimes supported with data) are recounted about how burglary rates were affected by interventions intended to change household gun prevalence. Finally, there have been two systematic studies, including regression analyses of panel data, on the effect of gun prevalence on overall (residential plus non-residential) burglary rates (Lott 2000; Duggan 2001).

\section{A. Frequency of gun use in self-defense}

The frequency with which guns are used in defense against burglary has been estimated from survey data from time to time. Unfortunately the estimates differ by an order of magnitude, depending on how the survey is conducted and what questions are asked.

At the high end is a 1994 random-digit-dial telephone survey that generated an estimate of 503,000 instances in the preceding 12 months in which some member of the household retrieved a gun to fend off an intruder who was actually seen (Ikeda et al. 1997). The survey was conducted by a private firm, DataStat, on behalf of the federal government. It completed 5,238 interviews, of which 22 respondents reported one or more uses of a gun in the event of an intruder; 5 of these accounted for nearly half of all the reported instances. Almost all of these reports $(98.9 \%)$ indicated that the intruder had been scared off.

At the low end are estimates based on the National Crime Victimization Survey (NCVS), which is conducted every six months by the U.S. Census Bureau. The NCVS includes respondents from a sample of about 50,000 households, the members of which are usually interviewed in person; the design of this survey represents best practice in the area. Based on a special tabulation of NCVS data by the Bureau of Justice Statistics, Cook (1991, p. 56) estimated that there were an annual average of just 32,000 instances per year for the period 1979-87 in which a householder used a gun against someone who broke into the home or attempted to do so.

Is the "right" answer 32,000 or 503,000? There is no obvious way to reconcile these two estimates. The same puzzle has arisen in survey-based estimates of self-defense uses of guns in other circumstances (Kleck and Gertz 1995; Smith 1997), which also differ by an order of magnitude, and that discussion will not be reviewed here. Suffice it to say that survey-based 
estimates for rare and normatively charged events such as gun self-defense are highly sensitive to survey method, and that we are inclined to place somewhat more faith in the NCVS results for reasons explained in our earlier work (Cook, Ludwig and Hemenway 1997).

Cook (1991) estimated that there were about 1.0 million burglaries each year of occupied residences during the period 1979-87. The NCVS estimate then implies that in one in every 30 such burglaries was a gun used in self-defense. The DataStat estimate suggests that fully half of such burglaries resulted in self-defense with a gun. The credibility of the "deterrence" claim depends in part on which of these two estimates is closer to the truth. ${ }^{4}$

\section{B. Interviews with Burglars}

Evidence directly relevant for judging the "deterrence" and "inducement" hypotheses comes from surveys of felons. For example, in one 1982 convenience sample of 1,823 state prisoners, 35 percent of respondents "strongly agreed" and 39 percent "agreed" that "one reason burglars avoid houses when people are at home is that they fear being shot." Of the respondents who used a gun to commit the crime for which they were incarcerated, 50 percent reported that the possibility of encountering an armed victim was "very important" in their decision to employ a gun, while another 12 percent reported that this motivation was "somewhat important" (Wright and Rossi 1994).

At the same time guns are of considerable value to burglars, who typically prefer items that are easy to carry, easily concealed, and have high "pound for pound value" (Shover, 1991, Wright and Decker, 1994). As one St. Louis burglar reported, "A gun is money with a trigger" (Wright and Decker, 1994). Another respondent in the same study expressed a preference for working in neighborhoods with high proportions of white residents since households in these areas are likely to have "the basics," include guns: "White people hunt a lot more so than blacks" (Wright and Decker, 1994, p. 90). ${ }^{5}$

Nearly half of the respondents to the prison survey mentioned above report that they have stolen a gun during their lifetimes; of this group, seventy percent usually steal guns to sell or

${ }^{4} \mathrm{~A}$ study of home-invasion burglaries (unwanted entry of a single-family home while one or more individuals were present in the home) in Atlanta based on 198 police reports during summer 1994 found that just 1.5\% of victims used a gun in self-defense (Kellermann et al., 1995).

${ }^{5}$ On the other hand, a burglar interviewed by Rengert and Wasilchick (1985) said that he shunned burglaries in neighborhoods in which the residents were of a different race because "You'll get shot if you're caught there (p. 62)." 
trade rather than to keep for themselves (Wright and Rossi 1994). ${ }^{6}$

\section{International Comparisons}

Since the prevalence of household gun possession is substantially higher in the United States than Canada, Britain, and other wealthy nations, it seems reasonable to test the "deterrence" hypothesis by comparing residential burglary rates and patterns across these nations. As it turns out, relevant data are hard to come by. The Uniform Crime Reports do not provide a basis for estimating the number of "hot" burglaries, nor do the police-recorded data systems of other countries. Relevant survey-based estimates can be generated for the U.S. from the NCVS, but no other country has an annual crime survey of comparable quality. ${ }^{7}$ There have been occasional crime surveys in other nations, which suggest that other countries tend to have a higher percentage of residential burglaries involving occupied dwellings than for the United States. Table 1 (top panel) lists some of the relevant estimates that have been reported by Kleck (1997) and Kopel (2001).

One obvious problem with these comparisons is that the hot burglary rate for each country or city is measured at a different point in time. For two countries - the United States and Great Britain - survey measures of hot burglary rates are available for a common year, 1998. When we standardize for period effects in this way, the difference across the two countries in the hot burglary rate is reduced from the factor of 4 or 5 to 1 reported by Kleck and Kopel (top panel) to a factor of about 2 to 1 (bottom panel).

But comparability problems remain. The bottom panel of Table 1 highlights one difference. In 28 percent of American burglaries NCVS respondents did not know their whereabouts at the time of the burglary, a category that is not included in the British Crime Survey (BCS). Judging from the open-ended narratives provided by BCS burglary victims, a number of cases in which the respondent apparently did not know whether anyone was at home at the time of the burglary are classified as "respondent home, unaware of the burglary." As

${ }^{6}$ The prevalence of gun theft in the Wright and Rossi (1982) convenience sample of prisoners is higher than in the nationally representative sample of prisoners interviewed as part of the 1991 Survey of Inmates of State Correctional Facilities, in which only 10 percent of respondents report ever having stolen a gun.

${ }^{7}$ One attempt to generate internationally comparable survey-based results is the United Nations-sponsored International Crime Survey. This survey includes the United States, but is far smaller and in other ways inferior to the NCVS. More to the point, it does not include items that would permit the estimate of a hot burglary rate. For more details see ictlaw.leidenuniv.nl/group/jfcr/www/icvs/Index.htm.

${ }^{8}$ Our best guess is that at least $7 \%$ and perhaps as many as $46 \%$ of the cases coded as "respondent home but unaware of burglary" in the BCS -- and thus counted as "hot" -- would be 
seen in the last row of Table 1, adjusting for this coding discrepancy between the BCS and NCVS lowers the hot burglary rate in the UK from $46 \%$ to between $36 \%$ and $45 \%$. ${ }^{9}$

More importantly, even if we had comparable data there would remain the fact that a variety of potential explanations are plausible for an observed difference in the percentage of residential burglaries that involve occupied dwellings. For example, when burglars are arrested the punishment is more certain and severe in the U.S. than in England and Wales (Table 2). The difference in penalties provides an alternative explanation for why American burglars take extra care to avoid contact with victims. American and British households differ in a variety of other ways as well that are likely to affect the cost-benefit calculus facing burglars, including substantial differences in the proportion of households that have dogs or lack men. Without controlling for the other differences that may be important, attributing the disparity in hot burglary rates to one particular difference - gun prevalence - is entirely unpersuasive.

\section{Case Studies}

A variety of anecdotes have been offered in support of the deterrence hypothesis (Kopel 2001), but few have been well documented. The case of Kennesaw, Georgia, which adopted a ordinance in 1982 requiring every household to keep a gun, has been particularly prominent. There have been several published analyses of the burglary trend in Kennesaw around the time of the ordinance, with contradictory results (Kleck 1991, pp. 136-38; McDowall, Lizotte, and Wiersema 1991; Kleck 1998). In any event, this is not a good test of the deterrence hypothesis,

coded as "victim location unknown" in the NCVS and counted as "cold" burglaries. This inference stems from the fact that many of the respondents in this BCS category discover evidence of the burglary only after the fact, in the form of damage or other signs of forcible entry. Examples of such cases include the BCS respondent who reported that "there was evidence on the patio door that a tool had been used to try to open it; the marks were noticed in April, we don't know when they tried to break in," and another who reported that "someone came into my flat, probably while I was asleep after my dinner, and stole a metal case." Cases in which the respondent simply reports finding evidence of an attempted break-in, but does not elaborate on his or her uncertainty about when the crime occurred or where he or she was at the time, are far more common.

${ }^{9}$ On the other hand differences in survey methods or reporting across countries could also in principle mask even larger differences in hot burglary rates than those reported in Table 1. The ratio of completed to attempted burglaries is far higher in the U.S. (3 or 4 to 1 ) than in the U.K. (nearly equal in most years) (Perkins et al., 1996, Home Office, 1999). One possible explanation for the relative scarcity of burglary attempts in the American NCVS data is that Americans are less likely then the English to report burglary attempts to interviewers. In this case, the denominator for the NCVS-based "hot burglary" calculations are too low, which could lead us to either over- or under-state the hot burglary rate in the U.S. depending on what fraction of the unreported burglary attempts are to occupied homes. 
since the ordinance in question was purely symbolic. Most homes in Kennesaw already had a gun prior to the ordinance, and it seems unlikely that the ordinance had an effect on prevalence since there was no penalty specified in the law for refusal to comply.

\section{E. Regression Analysis of Panel Data}

Two previous studies have examined the relationship between gun ownership and overall burglary rates within the U.S. Both studies rely on UCR data that lump together residential and non-residential burglary, and do not allow hot burglaries to be identified separately. These studies yield conflicting results about the relationship between gun prevalence and burglary rates.

Lott (2000) analyzes state-level UCR data for two years -- 1988 and 1996 -- and finds that after controlling for region and period effects as well as a variety of state co-variates, a one percentage point increase in gun-ownership rates reduces burglary rates by 1.6 percentage points. One problem with this analysis is Lott's choice of data to measure state gun ownership rates. He employs two voter-exit surveys that, among other problems, are not comparable with each other, as suggested by the fact that the individual gun-ownership rate is 10 percentage points higher in the 1996 survey than the 1988 survey, 37 percent versus 27 percent (Lott 2000, p. 36). In contrast, estimates from the General Social Survey, which has included items on guns since 1972 and is widely regarded as the best ongoing source of data on this topic, indicate that gunownership rates were actually declining slightly during this time period (Smith 2000).

Duggan (2001) uses a different measure for local gun prevalence - subscription rates to Guns \& Ammo Magazine. While Lott relies on state-level UCR data measured at just two points in time, Duggan uses county- and state-level UCR data for the period 1980-1998, which enables him to control for county or state fixed effects as well as other co-variates. Duggan's state-level analysis finds a positive and statistically significant relationship between changes in gun ownership rates and UCR burglary rates two years in the future, while the regression coefficient on the one-year lag of the change in gun prevalence is negligible.

\section{Measuring Crime Rates and Gun Prevalence}

Direct measures of burglary rates are available from two independent sources, the Uniform Crime Reports (UCR), which are tabulations of crime reported to and recorded by the police and then forwarded to the FBI, and the National Crime Victimization Survey (NCVS). For measuring gun ownership rates at the local level we rely on a well-validated proxy measure, the proportion of suicides that involve firearms.

\section{A. Uniform Crime Reports}

The FBI's UCR system compiles records each year from law enforcement agencies across the country for crimes known to the police. While the UCR is the only source for measuring annual crime rates for sub-national jurisdictions such as states or counties, these data have a number of problems. First, only a fraction of serious crimes are reported to the police, and the 
probability that victims do report crimes appears to be systematically related to factors such as socio-economic status, urbanicity and local police resources (Laub, 1981, Levitt, 1998a).

Second, some law enforcement agencies do not report complete crime information to the FBI in some years. The FBI attempts to fill in missing data by an imputation procedure which of course introduces another sort of error. Third, the published data on UCR burglary rates lump together residential and non-residential burglaries. While local jurisdictions are supposed to report a breakdown of burglary counts by the type of victim (residential or non-residential) and these data are available from the UCR in unpublished form, in practice the quality control on these data appears weaker than for the overall burglary counts. Nationwide, non-residential burglaries make up one-third of the total reported in the UCR (FBI 1996, p. 39).

The UCR data do not distinguish between burglaries of occupied and unoccupied buildings. In fact, some of the "hot" burglaries will not even be included in the UCR burglary count, since incidents are classified by the most serious of the crimes recorded by the police. If the police record that the perpetrator robbed the occupant after breaking into the dwelling, for example, then the entire incident is recorded as a robbery rather than a burglary.

Our calculations draw on UCR data for the period 1977 through 1998, measured at both the state and county levels. The advantage of using county-level data is that we are able to account for some sources of within-state heterogeneity. The disadvantage of the county data is that they appear to be far more sensitive to problems with the imputation methods used to correct for missing data (Maltz, 1999), and information on the local-area socio-demographic characteristics that may be relevant in explaining burglary rates are less readily available at the county than state level.

\section{B. National Crime Victimization Survey}

Since 1973 the National Crime Victimization Survey (NCVS) has provided analysts with a rich source of information on certain household and personal crimes. Conducted by the Census Bureau for the Bureau of Justice Statistics, the NCVS collects victimization reports from residents drawn from a sample of 50,000 to 60,000 housing units. Households are selected to participate using a multi-stage sampling procedure in which the probability of selection depends in part on the size of the respondent's county as well as other factors; sampling weights are provided with the NCVS to generate nationally representative estimates, which are used in all of the analysis that follows. Housing units selected for NCVS are interviewed initially in person, and then re-interviewed six more times at six-month intervals either in person or on the telephone. Surveys are conducted with every household resident who is 12 years of age or older, yielding a total of 90,000 to 100,000 survey responses. Response rates with the NCVS are typically on the order of 95 percent (Perkins et al., 1996).

Our analysis relies on a special restricted-use version of the NCVS that identifies the county in which survey respondents reside. This geo-coding enables us to merge information from the NCVS with a measure of gun prevalence in the respondent's county, as described in the 
next section. Given the limited number of years for which geo-coded NCVS data are available, ${ }^{10}$ we pool these data and focus our attention on cross-sectional analyses with the NCVS.

\section{Household Gun Prevalence}

Since the United States does not maintain a registry of guns in private hands, survey data are the primary means of generating national and regional estimates for gun ownership rates and patterns. According to the 1999 General Social Survey, 36\% of households own at least one firearm (Smith 2000, p. 52). Unfortunately neither the General Social Survey nor any other provides reliable estimates for each of the 50 states or for local jurisdictions. Hence, exploring the effect of gun prevalence at the sub-regional level requires use of a proxy variable.

Recent research demonstrates that among the readily computed proxies that have been used for this purpose, one has the greatest validity: the percentage of suicides committed with a gun. This proxy "outperforms" such measures as the percentage of homicides committed with a gun, the prevalence of membership in the National Rifle Association, or the subscription rates for gun-oriented magazines (Azrael, Cook and Miller 2001). As an example, the cross-section correlation between this proxy and survey-based estimates available for 21 states (from the Behavioral Risk Factor Surveillance System) is .90; the corresponding correlation for the subscription rate to Guns \& Ammo is .67, and to the NRA membership prevalence is .55.

Table 3 highlights the substantial variation in gun ownership across states within the U.S. Since suicide is a fairly rare event, in Table 3 and our other cross-sectional analyses we improve the reliability of our proxy measure by combining suicide data for the period 1987 through 1996. This measure ranges from near 30 percent in Hawaii and Massachusetts to over 75 percent in Louisiana, Alabama and Mississippi. While these examples highlight the substantial regional differences in gun ownership rates (Cook and Ludwig 1996; Glaeser and Glendon 1998), there is also considerable intra-regional variation. For example the proportion of suicides involving guns equaled 67 percent in Vermont, but only 57 percent in nearby New Hampshire and 31 percent in Massachusetts. In Illinois, guns were involved in 47 percent of suicides, compared with 55 and 63 percent in Wisconsin and Indiana, respectively. As demonstrated below there is also substantial within-state variation among counties, even when the sample is limited to the set of large counties (with populations of 100,000 or more) for which Vital Statistics reports separate county-level mortality information. ${ }^{11}$

${ }^{10}$ While geo-coded NCVS data are now available through restricted-use Census data centers for 1987 through 1998, our own analyses rely on data for the period 1994-1998. Even with the full 1987-98 sample, however, there is unlikely to be enough over-time variation in gun ownership rates to support a fixed-effects analysis, since (as we discuss below) there is only modest over-time variation even for the 1977-1998 period.

${ }^{11}$ We also exclude from our analytic sample counties that have fewer than 50 suicides during the 1987-1996 period, although this constraint excludes relatively few additional counties. 
Our ability to exploit standard panel-data techniques to control for confounding factors and reverse-causation is limited somewhat by the fact that the cross-section structure of gun ownership is quite stable over time. For example, in our state panel data for 1977-1998 fully 90 percent of the variation in gun ownership rates is cross-sectional. But as reported below, the inter-temporal variation is sufficient to generate reliable results.

\section{Gun Prevalence and Burglary Rates}

Our empirical strategy is to explore the effect of gun prevalence on burglary rates, and then, in the next section, turn to the specific matter of hot burglary. We begin by developing a simple model which demonstrates that the net effect of gun prevalence on residential burglary rates may be positive or negative, depending on the relative magnitude of the deterrence effect and what we are calling the "inducement" effect. We then estimate this relationship using data from the UCR and NCVS.

\section{A. Model}

The opposing effects of gun prevalence on residential burglary rates are highlighted by considering a simple model of the expected utility of a single burglary opportunity, as in equation (1). Let $\mathrm{G}$ represent the proportion of households in the community that possess guns, where $P$ is the probability that the burglar encounters an armed household resident and is shot, D is the utility associated with being shot (which we assume is independent of wealth) and $\mathrm{L}$ is the expected loot associated with committing a successful burglary. To further simplify the model, we assume that the burglar is risk neutral with respect to wealth, and is endowed with wealth W.

$$
\mathrm{E}[\mathrm{U}[\mathrm{G}]]=\mathrm{P}[\mathrm{G}] \times \mathrm{D}+(1-\mathrm{P}[\mathrm{G}]) \times(\mathrm{L}[\mathrm{G}]+\mathrm{W})
$$

The probability of being shot $(\mathrm{P})$ is an upward-sloping function of $\mathrm{G}$. The loot associated with successful burglaries (L) is a function of $\mathrm{G}$ with $\mathrm{L}^{\prime}>0$ because guns present an attractive target for theft. ${ }^{12}$

An increase in gun prevalence will increase the utility of this burglary prospect if the additional utility from increased loot outweighs the increased probability of suffering a loss in utility from being shot, as in (2). If burglars are able to determine which homes are occupied, reducing $P$ for a given level of $G$, then the inducement effect becomes more important compared to the deterrent effect. In the extreme case in which burglars are always able to avoid occupied

${ }^{12}$ Gun prices may also be relevant, in two opposing respects. First, as Mark Kleiman has pointed out to us, black-market gun prices may be inversely related to $\mathrm{G}$, which if true would weaken the argument that the expected loot increases with gun prevalence. By the same reasoning, it will be cheaper for burglars to arm themselves in cities with high gun prevalence, a fact that may be relevant to the extent that gun possession makes a burglar bolder. See Cook $(1976,1991)$ for a similar argument with respect to robbery. 
homes (that is, $\mathrm{P}=0$ ), more guns unambiguously increase the net gains to burglary.

$$
(1-\mathrm{P}) \mathrm{L}^{\prime}>\mathrm{P}^{\prime}(\mathrm{L}+\mathrm{W}-\mathrm{D})
$$

This result can be translated into a corresponding prediction about the burglary rate on the assumption that one such prospect is available to each potential burglar during each period. (The only complication has to do with the logical possibility that a burglar who is shot will drop out in subsequent periods.)

The model serves to demonstrate the possibility that more guns will result in more or fewer burglaries. Empirical work may help resolve this ambiguity.

\section{B. UCR Results}

We begin our empirical exploration using data from the Uniform Crime Reports, which are available for each year since 1977 and form the basis of earlier analyses on the same topic by Lott (2000) and Duggan (2001). ${ }^{13}$ Standard panel-data techniques yield a positive estimated relationship between changes in gun prevalence and changes in burglary rates. In an effort to deal with the possibility of omitted-variables bias, a set of estimates utilizing an instrumental variable for gun prevalence is also presented, with qualitatively similar findings.

\section{Panel Data Results}

The baseline model is described in equation (3), which we estimate using state-level UCR data. The key outcome measure of interest, $\Delta \mathrm{B}_{\mathrm{it}}$, equals the change in state i's burglary rate between period t-1 and t. The key explanatory variable of interest is the change in the state's gun index, $\Delta \mathrm{G}_{\mathrm{it}-1}$, which is lagged one period to minimize the problem of reverse causation; this problem arises because burglary rates may be the cause as well as the effect of gun prevalence if the demand for guns is influenced by a concern for defending against intruders. To reduce the measurement error associated with the gun proxy, each observation in our panel corresponds to a state rather than a county, and to a 3 -year rather than the more usual single-year period. ${ }^{14}$ Thus for the period 1977-1998 each state contributes seven observations to the panel. ${ }^{15}$ To control for possibly confounding factors the model conditions on a vector of state socio-demographic

${ }^{13}$ Because of problems with the crime data reported by law enforcement authorities to the UCR system (Maltz, 1999), our analytic sample excludes observations from Illinois, 1993-1998, Kansas, 1993-1998, Kentucky, 1996-1998, and New Hampshire, 1997.

${ }^{14}$ As it turns out, estimating equation (3) using single-year observations for each state rather than 3-year averages yields point estimates that are similar to those in Table 4 but with larger standard errors.

${ }^{15}$ The last observations in the series are for the 4-year period, 1995-1998. 
characteristics $\mathrm{X}_{\mathrm{it}}$ including per capita income, racial composition, prisoners per capita, the poverty rate, and alcohol consumption.

$$
\Delta \mathrm{B}_{\mathrm{it}}=\beta_{0}+\beta_{1} \Delta \mathrm{G}_{\mathrm{it}-1}+\beta_{2} \Delta \mathrm{X}_{\mathrm{it}}+\gamma_{\mathrm{i}}+\delta_{\mathrm{t}}+v_{\mathrm{it}}
$$

Since the outcome variable is measured in change rather than level form, the timeinvariant inter-state structure of burglary rates drops out. The model also includes state fixed effects $\left(\gamma_{\mathrm{i}}\right)$ to control for unmeasured factors that may change over time and drive state-specific trends in burglary rates, and period effects $\left(\delta_{t}\right)$ to adjust for nation-wide changes over time in burglary trends. Because a given change in gun prevalence may have a larger effect on burglary rates in areas where those rates are high, we also estimate a constant-proportional-effect version of equation (3) that uses the natural logarithm of the burglary rate as the outcome measure. To further control for time-varying unmeasured state attributes that may bias our findings, we reestimate equation (3) in a variety of alternative forms including models that condition on lagged changes in burglary rates, state-specific linear trends, and region-period interactions, as well as a version that controls for serial correlation by allowing the error structure in (3) to follow an autoregressive process that is unique to each state.

The UCR-based results are consistent in demonstrating that gun prevalence has a positive association with burglary. Table 4 summarizes the results for the coefficient and standard-error estimates on the gun-prevalence variable in our models. (Since the additional co-variates generally have the expected effect we do not focus on them in our discussion; the full set of coefficient estimates for the "base" model are relegated to the appendix, Table A1).

The base model includes state and year fixed effects and several co-variates. The estimated coefficients (reported in the first line of Table 4) are positive and statistically significant in both the linear and semi-log specifications, and imply an elasticity of burglary with respect to the gun-prevalence proxy on the order of +0.67 . The elasticity of burglaries with respect to gun ownership is slightly lower (around +0.4 or +0.5 ) because the proxy measure, while linearly related to gun prevalence over the relevant range, is not proportional (Azrael, Cook and Miller, 2001). ${ }^{16}$ For simplicity, and to facilitate comparisons with previous research, we focus in what follows on the elasticity of the burglary rate with respect to our gun proxy measure.

These findings are fairly robust to changes in how the model is estimated. Subsequent

16 The average burglary rate for the $1977-1998$ period was 1,276 per 100,000 , while the average value for our gun prevalence proxy equaled 58 and the average gun ownership rate in the US equaled around 40 percent. The discrepancy in elasticity estimates occurs because the gun proxy increases one-for-one with actual household gun ownership rates (Azrael, Cook and Miller, 2001), while the national average for the former is far higher than for the latter (58 versus 40 percent). Thus a 40 point increase in the proportion of suicides that involve guns represents around a 70 percent increase with respect to our gun proxy but a 100 percent increase in actual household gun ownership rates. 
lines of Table 4 report the results of conditioning on the lagged value of the dependent variable, including linear state-specific trends or region-period interaction terms in the model, or accounting for serial correlation in the error structure. Several of these changes reduce the magnitude of the coefficient on the gun proxy somewhat from the base model, but do not qualitatively change the findings. Using a model specification similar to that employed by Duggan (2001), in which the log burglary rate is regressed against the lagged and twice-lagged values of the log burglary and gun ownership variables, yields qualitatively similar findings (Table A1).

In part because the gun-prevalence variable is lagged in these regressions, it seems unlikely that the results reflect the reverse-causal effect of burglary rates on the demand for gun ownership. To further explore this possibility, we regress gun prevalence on the lagged burglary rate; that is, equation (3) is re-estimated with $B$ and $G$ interchanged. In this set up the coefficient estimate for the lagged burglary rate $\left(\Delta \mathrm{B}_{\mathrm{i}, \mathrm{t}-1}\right)$ is typically quite close to zero. Only when regionperiod interaction terms are included in the model does the burglary coefficient become statistically significant, and even then the implied elasticity is on the order of +0.06 or +0.07 , far smaller than the estimated effect of the lagged gun proxy on burglary rates. Thus it appears that gun prevalence drives burglary but burglary does not drive gun prevalence.

\section{Instrumental Variables Estimates}

Another way to address the endogeneity issue is by finding an instrument for gun prevalence that is not plausibly correlated with the error term in the burglary regression. The ideal instrument must pass three tests: highly correlated with gun prevalence, not affected by the current burglary rate, and uncorrelated with any influential omitted variables. The instrument that we use here exploits the fact that the cross-section structure of gun ownership rates has been highly stable over time, and is driven in large part by each area's local rural tradition (Azrael, Cook and Miller 2001). The instrument is the fraction of a state's population that lived in a rural area in 1950. It passes the first two tests: It is highly predictive of each state's gun ownership rate in the 1980's or 1990's, and is presumably not influenced by burglary rates occurring many years later. We have less confidence in how it does by the third test; "rural tradition" in a state may be correlated with other factors that influence burglary rates, not all of which are necessarily captured by the co-variates in our specification (which in this case include a measure of current urbanicity). Subject to that warning, we find that gun prevalence, as instrumented, tends to have a positive association with burglary rates.

The "instrumental variables" estimates come from estimating equations (4) and (5) using two-stage least squares. Because our instrument is defined by a single year's data (1950), we are limited to a cross-sectional analysis of burglary. In the equations $\mathrm{G}_{\mathrm{i}}$ represents state (i)'s gun ownership rate for the period 1987-1996, $\mathrm{B}_{\mathrm{i}}$ represents the state's average burglary rate over the period 1993 to $1995, \mathrm{X}_{\mathrm{i}}$ represents the average value of the state-level co-variates described above for the 1993-95 period (including a measure of the fraction of the state's population currently living in a metropolitan statistical area), and $R_{i}$ represents the fraction of state (i)'s population that lived in rural areas in 1950. The first-stage equation (4) yields a predicted value 
for each state's gun ownership rate, which is then substituted for the actual gun proxy in the second-stage equation (5).

$$
\begin{aligned}
& \mathrm{G}_{\mathrm{i}}=\alpha_{0}+\alpha_{1} \mathrm{R}_{\mathrm{i}}+\alpha_{2} \mathrm{X}_{\mathrm{i}}+\mathrm{v}_{\mathrm{i}} \\
& \mathrm{B}_{\mathrm{i}}=\theta_{0}+\theta_{1} \wedge \mathrm{G}_{\mathrm{i}}+\theta_{2} \mathrm{X}_{\mathrm{i}}+\mathrm{e}_{\mathrm{i}}
\end{aligned}
$$

Table 5 shows that the instrument $\mathrm{R}$ has a very strong relationship with cross-sectional variation in gun ownership rates. Using state-level cross-section data (top panel, Table 5) the Fstatistic for the significance of the instrument in the first-stage equation is equal to $20(p<.01)$, while the partial R-squared is equal to 0.03 . As seen in the bottom panel of Table 5, the instrument has similarly strong predictive power when gun-ownership levels are measured at the county level (with standard errors adjusted for the fact that the instrument varies at the state rather than county level).

The second stage estimates (Table 5) are positive, and thus consistent with a net inducement effect for both the state and county data. While the point estimates are not statistically significant, the implied elasticities of burglary with respect to gun ownership are equal to +0.46 and +0.41 , respectively, consistent with the panel-data results shown in Table 4. Estimating the instrumental variables model using a different three-year cross-section from the mid-1980's through the late 1990's yields qualitatively similar results to those shown in Table 5: the estimated effects of guns on burglary rates are positive or close to zero.

In interpreting the instrumental-variables estimates in Table 5 reverse causation can be ruled out, but there remains the possibility that the influence on current burglary rates of "\% rural in 1950" is not only through gun prevalence but also through some other mechanism not otherwise accounted for. Any bias that results from this problem is likely to exaggerate the deterrent effect of gun prevalence, because rural areas have on average lower burglary rates and higher gun ownership rates than urban areas even after conditioning on a variety of local-area characteristics. (See Appendix B for a formalization of this argument.) Because our IV strategy arguably overstates the deterrent effect of gun prevalence yet still yields estimates suggesting a net inducement effect, more guns seem more likely to lead to more than fewer burglaries. ${ }^{17}$

\section{NCVS Results}

The National Crime Victimization Survey (NCVS) provides an alternative source of data

${ }^{17}$ We also experimented with a variety of other instrumental variables although with little success. The proportion of households headed by a female has mixed predictive power in firststage equations. Since the second-stage point estimates are typically negative, equally consistent with either a net deterrent effect or the omitted variables bias that is likely to be in the direction of the deterrent effect, these results are not very informative. A variety of state sales and excise tax variables often had first-stage explanatory power, but failed standard over-identification tests. 
on residential burglary that is superior to the UCR data in a number of ways, as discussed above (section IIIA). The UCR, unlike the NCVS, lump together residential burglaries with commercial burglaries, only include crimes that happen to be reported to the police, and classify some incidents that included a burglary as robberies or assaults. Further they are only available at an aggregate level. The geo-coded version of the NCVS data allow a fine-grained analysis of geographic patterns in residential burglary. However, since we only have access to these data in geo-coded form for the period 1994-98, we cannot reproduce the analysis of intertemporal patterns reported in the previous section.

\section{The Probability of Burglary Victimization}

Table 6 reports the results of a cross-section regression analysis using almost 330,000 household survey responses taken from the 1994 through 1998 twice-annual waves of the NCVS. Only households in counties of population 100,000 or more are included. The dependent variable in each case is a $0-1$ indicator of whether or not the household reported being victimized by at least one illegal break-in or attempt during the preceding six months. The average for this variable is 2 percent. Variable definitions and means are in the appendix, Table A2.

The coefficients and standard errors are least-squares estimates, and are to be interpreted as the change in probability of burglary (in percentage terms) resulting from a one-unit increase in the independent variable. All our estimates are calculated using the survey's sampling weights, and Huber-White standard errors are calculated to adjust for the clustering of NCVS observations within counties. $^{18}$

Each regression controls for a variety of household characteristics, chosen in part on the basis of previous research (Smith and Jarjoura, 1989; Shover, 1991; Wright and Decker 1994). The three models differ with respect to the inclusion of other controls; Model 2 includes five county-level descriptors, while Model 3 includes a complete set of state fixed effects. ${ }^{19}$ As it turns out, most of the coefficient estimates on household characteristics are similar across the three models. Before commenting on the gun-prevalence estimates, we offer a few observations on the results for these household characteristics, which are not without interest in their own right.

The co-variates can be classified as either socio-economic-status (SES) variables, or as variables that characterize the vulnerability of the household to burglary. The results for the SES

${ }^{18}$ The choice of a linear-probability approach may be questioned: standard practice when there is a binary dependent variable is to estimate a non-linear form, such as a probit or logit. As a test, we ran a probit regression of the basic burglary specification. The qualitative results were unchanged from the linear-probability model.

${ }^{19}$ The purpose for including state fixed effects was to control for regional culture and the relevant characteristics of the state criminal-justice system. 
variables are quite consistent: burglary risk falls as education, age, or income increases. It is lower for households headed by a married couple rather than an unmarried adult, and is lower if the head is employed. Renter units are more likely to be burglarized than owner-occupied residences. Even accounting for those characteristics, blacks are more likely to be burglarized than whites or other ethnic groups.

The results for the variables that characterize vulnerability are also quite sensible. Households are more likely to be burglarized if living in an apartment building rather than freestanding residences; if located in the city rather than in the suburbs and rural areas of these (predominantly urban) counties; if the head is away from home most every night; and if it is new to the neighborhood, having moved in within the last two years. A bit mysterious is the finding that having children at home increases the risk of burglary victimization.

It is also of interest to note the estimated effects of county-population characteristics. These might be expected to influence the effectiveness of law enforcement, as well as the supply of criminals. As it turns out, racial composition, poverty, and female labor-force participation have little apparent effect on the likelihood of burglary victimization. Population density has a negative effect. ${ }^{20}$

The key explanatory variable of interest in these models is the proxy for gun-ownership prevalence, the proportion of suicides in the respondent's county that involved firearms during the 10 year period from 1987 through 1996. As seen in Table 6, the findings with respect to this variable are strong, and consistent with the findings from the UCR data. The probability of burglary victimization increases with gun prevalence in the county. In particular, an increase of 10 percentage points (from, say, 50 to 60) in the gun-prevalence indicator is associated with an increase in the probability of being burglarized by about 0.12 percent, for example from $1.80 \%$ to $1.92 \%$. These results imply an elasticity of burglary with respect to the gun proxy equal to .36 at the mean value of 54 .

Our preferred explanation for why higher gun prevalence would engender a higher burglary rate is in terms of the monetary payoff to burglary - guns are valuable loot because they are portable and are readily sold or fenced. The plausibility of this explanation is supported by an analysis of the likelihood that one or more guns is stolen in a burglary. Table 7 reports the results of a regression analysis of the 1994-1998 NCVS data. There are two sets of results. The first column reports the results of regressions on the entire sample where the dependent variable is a $0-1$ indicator of whether the household reported a gun stolen during the previous six months in a burglary. The second column reports results of regressions on the sub-sample of cases in

\footnotetext{
${ }^{20} \mathrm{We}$ also experimented with controlling for two county-level crime rates, motor-vehicle theft and larceny, either by themselves or in conjunction with the other county-level variables. These crime rates may be indicative of the supply of criminals in the county and of the effectiveness of the criminal justice system. Their inclusion had little effect on other results, and are not reported here.
} 
which there was a burglary. Each row of the table corresponds to a different specification of the regression, the same array as reported in greater detail in Table 6 . In every case the coefficient is positive and significantly different from zero, indicating the unsurprising result that higher gun prevalence is associated with more guns being stolen.

It should be noted, however, that the implied effect of gun prevalence on the overall profitability of residential burglary is not great. The likelihood of a gun being stolen in a successful residential burglary included in this sample is just 5.1\% overall; an increase of 10 points in the gun-prevalence proxy would increase the probability of guns being part of the loot by one percentage point. On the basis of data from a special study of burglaries in Prince Georges County, we estimate that the expected market value of this "prize" of about $\$ 30 .^{21}$ NCVS data for 1994-1998 suggest a somewhat higher value, perhaps as high as $\$ 70$ - equal to about $5 \%$ of the mean burglary $(\$ 1,505)$ and $20 \%$ of the median $(\$ 330) .{ }^{22}$ The actual value to the burglar depends on the local black market. In most cities the value would be less than in the licit market (Cook, Molliconi and Cole 1995).

This sort of expected-value calculation presumes that burglars encounter guns by chance. But in some burglaries the burglar has knowledge of the household and its possessions because he is a neighbor or ex-spouse or friend. In any event, it seems relevant that in 14 percent of the NCVS cases in which a gun was stolen, it was the only item stolen. ${ }^{23}$

${ }^{21}$ Data on successful burglaries in Prince Georges County, Maryland, were provided by the police for the years 1998-2000. There were 10,592 reported to the police during that time, of which $4.2 \%$ had at least one gun stolen. On average 1.8 guns were stolen, valued at an average of $\$ 327$.

${ }^{22}$ Our estimate is based on the 4,809 burglary cases reported by respondents to the NCVS between 1994 and 1998 in which something was stolen. While the NCVS does not provide information on the value of the stolen guns, it does provide information on the total value of all items that were stolen as well as the types of goods that were stolen. The value of the stolen guns to the victim is inferred by regressing the total value of what was stolen against indicators for the types of items that were taken. The regression also controls for household income, whether the home is owner-occupied, and the household head's educational attainment. The coefficient on the dummy variable indicating that guns were part of the loot equals $\$ 1,384$. That may be biased if burglaries in which guns are stolen tend to involve households with greater portable wealth in ways that are not fully reflected in the co-variates.

\footnotetext{
${ }^{23}$ In another 6 percent of cases in which guns were part of the loot, the only other item taken was cash.
} 


\section{Specification checks ${ }^{24}$}

How credible is the causal interpretation of the positive coefficient on gun prevalence? One concern is that gun prevalence may be correlated with an omitted variable that is in fact an important determinant of burglary. The most familiar approach to dealing with this possibility is to utilize instrumental variables, as we did in the previous section for the UCR data. We did in fact experiment with this approach for the NCVS data, and our results are reported in the next section. But first we present the results of a specification test in which other householdexperience variables which are unlikely to be influenced by gun prevalence are substituted for burglary victimization in the regressions. This test is motivated by the intuitive notion that if gun prevalence is statistically associated with these other outcome variables, then there must be an influential omitted variable in those regressions. Such a finding would suggest that there may also be an influential omitted variable in the burglary regressions.

The choice of alternative outcome measures with which to conduct this "test" seems fairly arbitrary. Our intuition was that it would be most meaningful to look at other types of crime victimization. Among the possibilities included in the NCVS, the most attractive option was motor-vehicle theft, a household crime (like burglary) that is almost always a crime of stealth, for which household gun ownership would matter very little either as a deterrent or enticement. We also analyzed two quite different variables from the NCVS, namely whether there was a telephone in the residence, and whether the respondent used public transportation.

Table 8 reports the results of re-running our basic set of regressions (from Table 6) for these outcomes. The first column repeats the estimated coefficients on gun prevalence for the burglary regressions. The second column gives the estimated coefficients when the same regressions are run with motor-vehicle theft in place of burglary as the dependent variable. The coefficient estimates are reassuringly close to zero in all specifications. "Telephone in residence" (the third column) has a negative relationship to gun prevalence, but the estimated coefficient shrinks to near zero when we introduce the county-level social and demographic co-variates. ${ }^{25}$

The final column of Table 8 reports the troubling results for the use of public transportation. The coefficient estimates are significantly negative in all specifications. While it is possible that gun prevalence does have a negative effect on use of public transportation, it seems unlikely that this mechanism is what explains these strong results - more likely is omittedvariable bias. Perhaps, for example, the missing variable is trust and support for government. Prevalent distrust of government and a taste for self-reliance may lead to more guns and less investment in public transit. Whether that same omitted variable is also present in the burglary

${ }^{24}$ Thanks to Bruce Sacerdote for suggesting this approach.

${ }^{25}$ Particularly important are the percentage of households that are headed by females (positively related to the prevalence to telephones) and the prevalence of poverty and of black households (both of which are negatively related). 
regressions is not clear; one test of these ideas proved inconclusive. ${ }^{26}$

\section{Results from Instrumental-Variable Regressions}

Table 9 presents the results of two-stage least-squares regressions that rely on the same instrument as in the UCR results, namely the percentage of the state population that lived in a rural area in 1950. This instrument performs very well in the first stage, and is positively related to burglary in the second stage. The magnitudes of the coefficient estimates are very similar to the magnitudes in the ordinary-least-squares analysis, but due to the inflated standard errors are no longer discernibly different from zero in a statistical sense.

We also ran these regressions with the other outcome variables, as in Table 8, and with very similar results. Coefficient estimates for motor-vehicle theft and telephone are insignificant, but the use of public transportation remains strongly negatively related to gun prevalence.

\section{Conclusions}

Taken together, the results reported here provide suggestive evidence that increases in gun ownership may lead to more burglaries. Using a new geo-coded version of the NCVS we estimate the elasticity of burglary-victimization probability with respect to our county-level gun proxy to be +0.3 to +0.4 , an estimate that is fairly robust to different specifications. Panel-data estimates from the UCR imply an elasticity of +0.6 to +0.7 . When we address the problem of reverse causation by instrumenting for current gun ownership rates using across-state variation in the proportion of the population living in rural areas in 1950 we obtain qualitatively similar results. While lagged urbanicity may well be correlated with unmeasured factors that affect burglary rates, the direction of bias runs in the opposite direction of our findings (towards overstating deterrence and understating inducement effects) and thus seems unlikely to explain away our IV findings. The causal mechanism by which higher gun prevalence would engender higher burglary rates could be through the effect on the value of loot.

\section{Guns and "Hot" Burglaries}

The empirical results reported above are for residential burglary of all kinds. But much of the public discussion concerning the possible deterrent value of guns has focused on "hot" burglaries of occupied dwellings. In what follows we use a simple model to demonstrate that an

${ }^{26}$ One proxy for "trust in government" is voting Democratic in a presidential election. We computed the percentage of Clinton voters who chose either Clinton or Dole in the 1996 presidential election for each of the counties included in our sample. When included in the "public transportation" regression that variable proved to have a significant positive effect, but with little effect on the coefficient on gun prevalence. The same was true when we included this co-variate in the burglary equation. 
increase in gun prevalence has an ambiguous effect on the rate of hot burglary. Cross-section NCVS regressions indicate that in practice local gun prevalence has little effect on the share of burglaries that are hot.

\section{A. Model}

The previous section developed a simple utility-maximizing model for burglars, which highlighted the ambiguous effects of changes in gun prevalence on the overall burglary rate. The effect of guns on hot burglaries is highlighted by the aggregate burglary equation (6), in which $\mathrm{G}$ (as before) is the proportion of households that keep guns, $\mathrm{H}[\mathrm{G}]$ represents the rate of hot burglaries, $\mathrm{h}[\mathrm{G}]$ represents the proportion of burglaries that are hot, and $\mathrm{B}[\mathrm{G}]$ represents the overall burglary rate.

$$
\begin{aligned}
& \mathrm{H}[\mathrm{G}]=\mathrm{h}[\mathrm{G}] \times \mathrm{B}[\mathrm{G}] \\
& \mathrm{H}^{\prime}=\mathrm{h}^{\prime} \mathrm{B}+\mathrm{hB}^{\prime}
\end{aligned}
$$

In this setup an increase in gun ownership has an ambiguous net effect on the rate of hot burglaries, as suggested by equation (7). The sign of $\mathrm{B}^{\prime}$ must be determined empirically, since more guns may in theory lead to either more or fewer burglaries. The empirical findings from Section IV suggest that more guns increase the burglary rate, in which case the second term on the right hand side of equation (7), $\mathrm{B}^{\prime} \mathrm{h}$, is positive. The sign of the first term on the right hand side of $(7)$ is negative $\left(h^{\prime}<0\right)$ if higher gun prevalence diverts burglars away from occupied homes through a deterrent effect, and positive if the opportunity to steal a gun is worth enough so that higher gun prevalence encourages burglars to take a greater chance.

Even if more guns in circulation causes burglars to take extra care to avoid occupied homes, the effect on the parameter of greatest policy interest - the probability that an occupied home is burgled - is ambiguous because of the increase in the total number of burglaries.

\section{B. NCVS Results}

The results from a cross-sectional analysis of NCVS data from 1994-1998 are presented in Table 10. The first column of estimates are of the effect of gun prevalence on the likelihood that someone is at home when there is a burglary ( 22 percent on average). While the coefficient estimates are negative in every case (suggesting a deterrent effect), they are not discernibly different from zero, and in all but the simple regression have t-statistics less than one. While null findings may sometimes simply reflect a lack of statistical power, in this case the NCVS data support a quite precise estimate, with the standard errors all less than one-tenth of one percentage point.

If, as suggested by these results, more guns lead to more burglaries but do not change the proportion of burglaries that are hot, we would expect an increase in gun prevalence to be associated with higher rates of hot burglary. Consistent with this expectation, the estimates 
reported in the last column of Table 10 indicate that an increase in gun prevalence increases the probability that a household is victimized by a hot burglary. A 10 percentage-point increase in the gun proxy increases the rate of hot burglaries by .03 or .04 percent, roughly in proportion to the increase in the overall burglary rate. ${ }^{27}$

\section{Discussion}

Our paper is motivated by the plausible although untested claim that widespread gun ownership deters burglars and diverts them from occupied homes. Previous evidence on this point is indirect, anecdotal, or based on flawed data, and in any case provides no clear conclusion.

The new results reported here suggest that if there is such a deterrent effect, it may well be swamped by other factors associated with gun prevalence - most likely, it seems to us, the fact that guns are particularly attractive loot. Cross-section analysis of the NCVS and panel-data analysis of the UCR yield quite similar findings: a 10 percent increase in our measure of gun ownership increases burglary rates by 3 to 7 percent. These results are not likely to be due to reverse causation: Among other evidence on this matter is the findings from our instrumentalvariable estimates, which are consistent with the OLS results. Most important, we find that gun prevalence has little effect on the fraction of residential burglaries in which someone is at home, and that the hot-burglary victimization rate tends to increase with gun prevalence. These results are robust to alternative specifications and data sets.

We conclude that keeping a gun at home is unlikely to provide a positive externality in the form of burglary deterrence. If anything, residences in a neighborhood with high gun prevalence are at greater risk of being burglarized, both hot and otherwise. There is an irony here: guns are often kept to protect the home, but the aggregate effect of individual decisions to keep guns at home appears to be an increase in the victimization rate.

${ }^{27} \mathrm{We}$ also repeated these OLS estimates for a sample restricted to a group that is unusually susceptible to hot burglary rates, female-headed households. The results are qualitatively similar, although with larger standard errors. 


\section{References}

Armstrong, Thomas (2000) "Will more gun control just do more harm?" San Diego UnionTribune. March 23: B13.

Australian Broadcasting Corporation (2001) "Queensland Police Review Security After Guns Stolen from Circulation." May 24, 2001.

Ayres, Ian and Steven Levitt (1998) "Measuring Positive Externalities from Unobservable Victim Precaution: An Empirical Analysis of Lojack." Quarterly Journal of Economics. 113.

Azrael, Deborah, Philip J. Cook, and Matthew Miller (2001) "State and Local Prevalence of Firearms Ownership: Measurement, Structure, and Trends." Cambridge, MA: National Bureau of Economic Research Working Paper \# 8570.

Bound, John, David A. Jaeger, and Regina M. Baker (1995) "Problems with Instrumental Variables Estimation When the Correlation Between the Instruments and the Endogenous Explanatory Variable is Weak." Journal of the American Statistical Association. 90(430): 443450.

Bureau of Justice Statistics (1997) Criminal Victimization 1996: Changes 1995-96 with Trends 1993-1996. NCJ-165812. U.S. Department of Justice, Bureau of Justice Statistics: Washington, DC.

Cook, Philip J. (1976) “A Strategic Choice Analysis of Robbery.” In Wesley Skogan (Ed.) Sample Surveys of Victims of Crime. Ballinger. pp. 173-187.

Cook, Philip J. (1987) “Robbery Violence.” Journal of Criminal Law and Criminology. 70(2).

Cook, Philip J. (1991) "The Technology of Personal Violence." In Crime and Justice: An Annual Review of Research. Edited by Michael Tonry. Chicago: University of Chicago Press. pp. 1-71.

Cook, Philip J. and James A. Leitzel (1996) "Perversity, Futility, Jeopardy': An Economic Analysis of the Attack on Gun Control." Law and Contemporary Problems. 59(1): 91-118.

Cook, Philip J. and Jens Ludwig (1996) Guns in America: Results of a Comprehensive Survey of Gun Ownership and Use. Washington, DC: Police Foundation.

Cook, Philip J. and Jens Ludwig (1998) "Defensive Gun Uses: New Evidence from a National Survey." Journal of Quantitative Criminology. 14(2): 111-131.

Cook, Philip J. and Jens Ludwig (2000) Gun Violence: The Real Costs. New York: Oxford University Press. 
Cook, Philip J. and Jens Ludwig (2001) "Regulation through Litigation: The Case of Firearms." In Litigation as Regulation. Edited by W. Kip Viscusi. Washington, DC: Brookings. In press.

Cook, Philip J., Jens Ludwig and David Hemenway (1997) "The Gun Debate's New Mythical Number: How Many Defensive Uses Per Year?" Journal of Policy Analysis and Management. 16: 463-469.

Cook, Philip J., Stephanie Molliconi, and Thomas B. Cole (1995) "Regulating Gun Markets." Journal of Criminal Law and Criminology. 86: 59-92.

Cutler, David M., Edward L. Glaeser, and Karen E. Norberg (2001) "Explaining the Rise in Youth Suicide." In Risky Behavior Among Youths: An Economic Analysis. Jonathan Gruber (Ed). Chicago: University of Chicago Press. pp. 219-270.

Duggan, Mark (2001) “More Guns, More Crime.” Journal of Political Economy 109(5), October: 1086-1114.

Duggan, Mark (2002) "The Relationship Between Gun Ownership and Suicide: Correlation or Causation?" This volume

Federal Bureau of Investigation (1996) Crime in the United States, 1995. Washington, DC: US Government Printing Office.

Federal Bureau of Investigation (1999) Crime in the United States, 1998. Washington, DC: US Government Printing Office.

Glaeser, Edward L. and S. Glendon (1998) "Who Owns Guns? Criminals, Victims, and the Culture of Violence." American Economic Review. 88(2): 458-462.

Hemenway, David (1997a) "The Myth of Millions of Self-Defense Gun Uses: An Explanation of Extreme Over-Estimates." Chance. 10: 6-10.

Hemenway, David (1997b) "Survey Research and Self-Defense Gun Use: An Explanation of Extreme Over-Estimates." Journal of Criminal Law and Criminology. 87: 1430-1445.

Ikeda, Robin M., Linda L. Dahlberg, Jeffrey J. Sacks, James A. Mercy, and Kenneth E. Powell (1997). "Estimating Intruder-Related Firearm Retrievals in U.S. Households, 1994." Violence and Victims, 12(4): 363-372.

Kellermann, Arthur L. and Donald T. Reay (1986) "Protection or Peril? An Analysis of FirearmRelated Deaths in the Home" New England Journal of Medicine 314, June 12: 1557-1560.

Kellermann, Arthur L., Lori Westphal, Laurie Fischer, and Beverly Harvard (1995) "Weapon Involvement in Home Invasion Crimes" Journal of the American Medical Association 273(22), 
June 14: 1759-1762.

Kleck, Gary (1991) Point Blank. New York: Aldine deGruyter.

Kleck, Gary (1997) Targeting Guns: Firearms and Their Control. New York: Aldine de Gruyter.

Kleck, Gary (1998) “Has the Gun Deterrence Hypothesis Been Discredited?” Journal of Firearms \& Public Policy v. 10: 65-.

Kleck, Gary and Marc Gertz (1995) “Armed Resistance to Crime: The Prevalence and Nature of Self-Defense With a Gun.” Journal of Criminal Law and Criminology. 86: 150-187.

Kopel, David B. (2001) "Lawyers, Guns, and Burglars” Arizona Law Review 43(2), Summer: 345-367.

Laub, John H. (1981) "Ecological Considerations in Victim Reporting to the Police." Journal of Criminal Justice. 9: 419-430.

Lee, Roberta K., Richard J. Waxweiler, James G. Dobbins, and Terri Paschetag (1991) "Incidence Rates of Firearm Injuries in Galveston, Texas, 1979-1981." American Journal of Epidemiology 134(5): 511-521.

Levitt, Steven D. (1997) "Using Electoral Cycles in Police Hiring to Estimate the Effect of Police on Crime." American Economic Review. 87(3): 270-290.

Levitt, Steven D. (1998a) "The Relationship between Crime Reporting and Police: Implications for the Use of Uniform Crime Reports." Journal of Quantitative Criminology. 14: 61-81.

Levitt, Steven D. (1998b) "Why Do Increased Arrest Rates Appear to Reduce Crime: Deterrence, Incapacitation, or Measurement Error?" Economic Inquiry. 36(3):353-372.

Lott, John R. (2000) More Guns, Less Crime, $2^{\text {nd }}$ ed. . Chicago: University of Chicago Press.

Ludwig, Jens (2000) "Gun Self-Defense and Deterrence." Crime and Justice: A Review of Research, Volume 27. Michael Tonry (Ed.). Chicago: University of Chicago Press. pp. 363-417.

Ludwig, Jens and Philip J. Cook (2000) "Homicide and Suicide Rates Associated with Implementation of the Brady Handgun Violence Prevention Act." Journal of the American Medical Association. 284(5): 585-591.

Ludwig, Jens and Philip J. Cook (2001) "The Benefits of Reducing Gun Violence: Evidence from Contingent-Valuation Survey Data." Journal of Risk and Uncertainty, 22(3): 207-226. 
Maltz, Michael D. (1999) Bridging Gaps in Police Crime Data. Washington, DC: U.S. Department of Justice, Bureau of Justice Statistics. NCJ 176365.

Miller, Matthew, Deborah Azrael, and David Hemenway (in press)

Miller, Matthew and David Hemenway (2000) "The Relationship Between Firearms and Suicide: A Review of the Literature." Aggression and Violent Behavior. 4(1): 59-75.

Perkins, Craig A., Patsy A. Klaus, Lisa D. Bastian, and Robyn L. Cohen (1996) Criminal Victimization in the United States, 1993: A National Crime Victimization Survey Report. Washington, DC: U.S. Department of Justice, Bureau of Justice Statistics. NCJ 151657.

Rengert, George and John Wasilchick (1985) Suburban Burglary: A Time and a Place for Everything.

Rowe, Dan (2001) "Expert Links Gun Control to High Rate of Break-Ins." National Post (Canada). December 19.

Shover, Neal (1991) "Burglary." In Crime and Justice: An Annual Review of Research, Volume 14. Edited by Michael Tonry. Chicago: University of Chicago Press. pp. 73-113.

Smith, Douglas A. and G. Roger Jarjoura (1989) "Household Characteristics, Neighborhood Composition and Victimization Risk." Social Forces. 68(2): 621-640.

Smith, Tom W. (2000) 1999 National Gun Policy Survey of the National Opinion Research Center: Research Findings. NORC, University of Chicago.

Steyn, Mark (2000) "In the absence of guns: In Britain, defending your property can get you life" The American Spectator. June.

Tucker, William (1996) "Maybe you should carry a handgun" Weekly Standard 2(14), Dec. 16: 30 .

United Nations (1998) United Nations International Study on Firearm Regulation. New York: United Nations.

White, A (1983) "Response Rate Calculation in RDD Telephone Health Surveys: Current Practices." In Proceedings of the American Statistical Association, Section on Survey Research Methods. Washington, DC: American Statistical Association. pp. 277-282.

Witkin, Gordon (1994) “Should you own a gun?” USNews. August 15, 117(7): 24.

Wright, James D. and Peter H. Rossi (1994) Armed and Considered Dangerous: A Survey of Felons and Their Firearms (Expanded Edition). New York: Aldine de Gruyter. 
Wright, Richard T. and Scott H. Decker (1994) Burglars on the Job. Boston: Northeastern University Press.

Zimring, Franklin E. (1968) "Is Gun Control Likely to Reduce Violent Killings?" University of Chicago Law Review. 35: 21-37.

Zimring, Franklin E. (1972) "The Medium is the Message: Firearm Calibre as a Determinant of Death from Assault." Journal of Legal Studies. 1: 97-124. 
Table 1

International Comparisons of Hot Burglary Rates

\begin{tabular}{|c|c|c|c|}
\hline Source & Country & Year & Hot burglary rate \\
\hline Mayhew et al. $(1993)^{\mathrm{a}}$ & UK & 1982-1988 & $43 \%$ \\
\hline Block $(1984)^{a}$ & Netherlands & 1977 & $48 \%$ \\
\hline Waller \& Okihiro (1978) & Toronto & $? ?$ & $44 \%$ \\
\hline Block $(1984)^{\mathrm{a}}$ & United States & 1976 & $9 \%$ \\
\hline BJS $(1985)^{b}$ & United States & 1983 & $12 \%$ \\
\hline BJS (1999) & United States & 1998 & \\
\hline Resident at home & & & $20.5 \%$ \\
\hline $\begin{array}{l}\text { Residents' location at time of } \\
\text { burglary unspecified or unknown }\end{array}$ & & & $28.3 \%$ \\
\hline Home Office (1999) & UK & 1998 & \\
\hline Resident at home & & & $46 \%$ \\
\hline Aware of burglary & & & $25 \%$ \\
\hline Unaware of burglary & & & $21 \%$ \\
\hline Adjusted UK "hot" burglary rate & UK & 1998 & \\
\hline Upper bound & & & $45 \%$ \\
\hline Lower bound & & & $36 \%$ \\
\hline
\end{tabular}

NOTES: $\mathrm{a}=$ Cited in Kleck (1997). $\mathrm{b}=$ Cited in Kopel (2001). $\mathrm{c}=$ Figures taken from BJS (1996, p. 70) reports for victim's activity at time of burglary; $24.5 \%$ of respondents report that they were sleeping or engaging in some other activity at home at the time of the burglary. Our high end estimate comes from including the $3.9 \%$ of respondents who say at the time of the burglary they were engaged in some other activity (unspecified whether this was at home or elsewhere) and the $16.2 \%$ did not know what they were doing at the time of the burglary. 


\section{Table 2}

Socio-economic and other differences between US and UK, 1998

\begin{tabular}{|c|c|c|}
\hline & United States & United Kingdom \\
\hline \multicolumn{3}{|l|}{ Avg punishment for burglars, $1996^{*}$} \\
\hline Convictions per 1,000 burglary arrests & 10 & 6 \\
\hline Probability of custody given conviction & $55 \%$ & $45 \%$ \\
\hline Avg time served for those given custody & 15 months & 7 months \\
\hline$\%$ households headed by single female & $29 \% 1$ & $22 \%{ }^{2}$ \\
\hline $\begin{array}{l}\% \text { people living in free-standing single- } \\
\text { family homes }\end{array}$ & $63 \%{ }^{7}$ & $\begin{array}{l}23 \% \text { (living in detached } \\
\text { house) })^{2}\end{array}$ \\
\hline$\%$ people living in mobile homes/trailers & $6.6 \%{ }^{7}$ & $\begin{array}{l}\text { no indication of mobile } \\
\text { homes/trailers present } \\
\text { in UK }\end{array}$ \\
\hline$\%$ people who own their own home & $66 \%{ }^{6}$ & $69 \% \%^{2}$ \\
\hline \multicolumn{3}{|l|}{$\begin{array}{l}\% \text { households that contain male between } \\
20 \text { and } 60\end{array}$} \\
\hline median income & $\begin{array}{l}\$ 38,233(1997-1998 \\
{\text { two-year average })^{3}}^{3}\end{array}$ & \\
\hline$\%$ households that contain children & $\begin{array}{l}34 \% \text { (child is under } \\
18)^{1}\end{array}$ & $\begin{array}{l}29 \%(\text { youngest person } \\
\text { under } 15)^{2}\end{array}$ \\
\hline$\%$ population non-white & $17 \%{ }^{1}$ & $7 \%{ }^{2}$ \\
\hline $\begin{array}{l}\text { population density (population per square } \\
\text { mile) }\end{array}$ & $76.4^{1}$ & \\
\hline$\%$ people living in urban areas & $80 \%(\text { as of } 1996)^{1}$ & \\
\hline$\%$ households that own dogs $* *$ & $40 \%$ & $20 \%$ \\
\hline \multicolumn{3}{|c|}{$\begin{array}{l}\text { Data Sources: }{ }^{1} \text { U.S. Census Bureau, Statistical Abstract of the United States: } 1999 .{ }^{2} \text { Living in Britain 1998: } \\
\text { General Household Survey. }{ }^{3} \text { U.S. Census Bureau, Current Population Survey, March 1997, 1998, and } 1999 . \\
{ }^{4} \text { Criminal Statistics, England and Wales, } 1997 \text { (The Stationery Office) and findings from the British Crime Survey } \\
\text { Criminal Sentencing Statistics, Bureau of Justice Statistics, U.S. Department of Justice, } 1998 \\
{ }^{5} \text { U.S. Census Bureau, Housing Vacancy Survey, Third Quarter } 2001{ }^{7} \text { U.S. Census Bureau, American Housing } \\
\text { Survey for the United States: } 1999{ }^{*} \text { UK figure is for England and Wales, provided courtesy of David Farrington. } \\
\text { Figure for probability of custody given conviction for England and Wales for 1997. }{ }^{* *} \text { Figure for UK is for } 2000 \\
\text { from Claritas Precision Marketing Solutions (www.claritas-europe.com). Figure for US is taken from the American } \\
\text { Pet Products Manufacturers Association 2001-2002 National Pet Owners Survey (summary statistics downloaded } \\
\text { from www.hsus.org/programs/companion/overpopulation/petowner_stats.html). }\end{array}$} \\
\hline
\end{tabular}


Table 3

Ranking of States by Gun-Prevalence Proxy

\begin{tabular}{|c|c|}
\hline State & $\%$ suicides 1987-1996 involving firearm \\
\hline Hawaii & 28.1 \\
\hline Massachusetts & 31.0 \\
\hline Rhode Island & 34.9 \\
\hline New Jersey & 35.2 \\
\hline New York & 38.6 \\
\hline District of Columbia & 38.6 \\
\hline Connecticut & 44.8 \\
\hline Illinois & 46.9 \\
\hline Minnesota & 49.8 \\
\hline Delaware & 50.6 \\
\hline California & 53.0 \\
\hline Iowa & 53.6 \\
\hline Wisconsin & 54.8 \\
\hline Pennsylvania & 54.9 \\
\hline Maryland & 55.5 \\
\hline Colorado & 56.5 \\
\hline Washington & 57.1 \\
\hline Michigan & 57.1 \\
\hline New Hampshire & 57.2 \\
\hline Nebraska & 58.5 \\
\hline North Dakota & 59.2 \\
\hline Ohio & 59.8 \\
\hline Maine & 60.4 \\
\hline Florida & 60.5 \\
\hline Utah & 60.9 \\
\hline Oregon & 61.8 \\
\hline South Dakota & 62.7 \\
\hline Indiana & 62.9 \\
\hline Kansas & 64.3 \\
\hline New Mexico & 64.4 \\
\hline Missouri & 65.1 \\
\hline Nevada & 66.0 \\
\hline Vermont & 66.7 \\
\hline Montana & 67.6 \\
\hline Arizona & 67.8 \\
\hline Virginia & 67.8 \\
\hline Texas & 69.0 \\
\hline Alaska & 70.6 \\
\hline Idaho & 70.7 \\
\hline Oklahoma & 71.0 \\
\hline North Carolina & 71.5 \\
\hline South Carolina & 72.3 \\
\hline Kentucky & 74.4 \\
\hline Georgia & 74.5 \\
\hline Tennessee & 75.0 \\
\hline Wyoming & 75.1 \\
\hline West Virginia & 75.9 \\
\hline Arkansas & 76.3 \\
\hline Louisiana & 76.3 \\
\hline Alabama & 78.0 \\
\hline Mississippi & 80.2 \\
\hline
\end{tabular}


Table 4

\section{Effects of Gun Prevalence on Burglary Rates \\ Repeated 36-Month Cross-Sections \\ UCR State-Level Data, 1977-1998 \\ Coefficients and Standard Errors}

\begin{tabular}{lll}
\hline & $\begin{array}{c}\text { Dependent variable: } \\
\text { Coefficient on lagged } \Delta \text { gun-prevalence }\end{array}$ & $\begin{array}{l}\Delta \text { log UCR burglary } \\
\text { rate }\end{array}$ \\
\hline variable in specified model: & $14.62^{\mathrm{b}}$ & $0.0115^{\mathrm{b}}$ \\
Base model* & $(6.78)$ & $(0.0045)$ \\
& $609^{\mathrm{c}}$ & $0.4898^{\mathrm{b}}$ \\
Use $\Delta$ log gun prevalence in base model & $(331)$ & $(0.2306)$ \\
& $9.67^{\mathrm{b}}$ & $0.0076^{\mathrm{b}}$ \\
Condition on lagged dep variable in base model & $(4.75)$ & $(0.0033)$ \\
& 11.11 & 0.0090 \\
Add linear state-specific trends in base model & $(7.84)$ & $(0.0053)$ \\
& 9.00 & $0.0075^{\mathrm{c}}$ \\
Add region / year interactions to base model & $(6.46)$ & $(0.0044)$ \\
Correct for serial correlation in error term & $(3.81)$ & $0.0115^{\mathrm{b}}$ \\
\hline
\end{tabular}

NOTES: * = Base model also includes state and year fixed effects, as well as controls for state unemployment rate, median per capita income, alcohol consumption per capita, percent poor, and percent black. State population used as weights; robust standard errors in parentheses. The correction for serial correlation allows the inter-temporal correlation in the error structure to be state-specific. $^{* *}=$ County level model controls for county and year fixed effects, per capita income and unemployment rate. Data available only through 1995. b = Statistically significant at 5 percent level, $\mathrm{c}=$ Statistically significant at 10 percent level. 
Table 5

\section{Instrumental Variables Analysis of Effect of Guns on Burglary \\ UCR State- and County-Level Data \\ Point Estimates and Standard Errors}

\section{STATE LEVEL DATA}

First stage results

Effects of \% rural, 1950 on \% suicides w/ guns, 87-96 (beta, se)

F-statistic on instrument (df)

$0.60(.13)^{\mathrm{b}}$

Partial R-squared on instrument

$20.0(1,47)^{\mathrm{b}}$

.0296

$\underline{\text { Second stage results }}$

Effect of \% suicides w/ guns, 87-96 on average burglary rate, 93-95

(beta, se)

$10.11(10.99)$

\section{COUNTY LEVEL DATA}

First stage results

Effects of \% rural, 1950 on \% suicides w/ guns, 87-96 (beta, se)

F-statistic on instrument (df)

$0.34(.06)^{\mathrm{b}}$

Partial R-squared on instrument

.0751

$\underline{\text { Second stage results }}$

Effect of \% suicides w/ guns, 87-96 on average burglary rate, 93-95

(beta, se)

NOTES: Regression model for state-level estimates include co-variates for state age and race distribution, region, prisoners per capita, unemployment rate, poverty rate, and percent living in metropolitan areas. Regression model for county-level data controls for region, county per capita income, and unemployment rate. All regressions estimated using state (county) population as weights. $b=$ Statistically significant at 5 percent level. 
Table 6

Determinants of Burglary-Victimization Probability

Cross-Section OLS Regression Results

NCVS Data, 1994-1998

Coefficients and Standard Errors (x100)

\begin{tabular}{|c|c|c|c|}
\hline \multirow[b]{2}{*}{ Explanatory Variable } & \multicolumn{3}{|c|}{ Dependent Variable $=$ burglary in previous 6 month } \\
\hline & Model 1 & Model 2 & Model 3 \\
\hline A. Gun Prevalence & $\begin{array}{c}.0137^{\mathrm{a}} \\
(.0030)\end{array}$ & $\begin{array}{c}.0110^{\mathrm{b}} \\
(.0043)\end{array}$ & $\begin{array}{c}.0126^{\mathrm{b}} \\
(.0053)\end{array}$ \\
\hline \multicolumn{4}{|l|}{ B. Residential Characteristics } \\
\hline \multicolumn{4}{|l|}{ 1. Type of Building } \\
\hline a. 1 Unit & ---- & ---- & ---- \\
\hline b. 2-4 units & $\begin{array}{l}-.1266 \\
(.1027)\end{array}$ & $\begin{array}{l}-.1388 \\
(.1036)\end{array}$ & $\begin{array}{l}-.1400 \\
(.1027)\end{array}$ \\
\hline c. 5 or more units & $\begin{array}{l}-.7208^{a} \\
(.1034)\end{array}$ & $\begin{array}{l}-.7184^{\mathrm{a}} \\
(.1033)\end{array}$ & $\begin{array}{l}-.7524^{\mathrm{a}} \\
(.0992)\end{array}$ \\
\hline d. Mobile home & $\begin{array}{l}.3494^{\mathrm{c}} \\
(.2032)\end{array}$ & $\begin{array}{c}.3330 \\
(.2057)\end{array}$ & $\begin{array}{c}.2505 \\
(.2064)\end{array}$ \\
\hline e. Other type & $\begin{array}{l}-.5303 \\
(.3330)\end{array}$ & $\begin{array}{c}-.5044 \\
(.3350)\end{array}$ & $\begin{array}{c}-.4290 \\
(.3272)\end{array}$ \\
\hline
\end{tabular}

2. Location
a. Urban area
b. Suburban area
$-.5711^{\mathrm{a}}$
$-.4981^{\mathrm{a}}$
$-.5434^{\mathrm{a}}$
(.0754)
(.0763)
(.0749)
c. Rural area
$-.6773^{\mathrm{a}}$
$-.6081^{\mathrm{a}}$
$-.4483^{b}$
(.2020)
(.1901)
$(.1951)$

C. Household characteristics

1. Male head

$-.2144^{\mathrm{a}}$
$(.0645)$

$-.2115^{\mathrm{a}}$

$-.2016^{\mathrm{a}}$

(.0632)

(.0628)

2. Renter occupied

$.3912^{\mathrm{a}}$

$.3816^{\mathrm{a}}$

$.3797^{\mathrm{a}}$

(.0863)

(.0862)

(.0850)

3. Children under 12

\begin{tabular}{cccc} 
a. None & --- & --- & --- \\
\hline b. 1 & $.2570^{\mathrm{a}}$ & $.2466^{\mathrm{b}}$ & $.2418^{\mathrm{b}}$ \\
& $(.0956)$ & $(.0963)$ & $(.0965)$ \\
\hline
\end{tabular}



c. 2 or more
$.5872^{\mathrm{a}}$
$.5705^{\mathrm{a}}$
$.5549^{\mathrm{a}}$
(.0938)
(.0945)
(.0939)

4. Children over 12
a. None or 1
b. 2
$.1865^{\mathrm{b}}$
$.1807^{\mathrm{b}}$
$.1697^{\mathrm{b}}$
(.0839)
(.0833)
(.0835)
c. 3 or more
$.9443^{\mathrm{a}}$
$.9227^{\mathrm{a}}$
$.9116^{\mathrm{a}}$
(.0979)
(.0987)
(.0987)

5. Time at address
a. More than 2 years
b. Two years or less
$.1858^{\mathrm{b}}$
$.1884^{\mathrm{b}}$
$.1759^{\mathrm{b}}$
(.0779)
(.0779)
(.0787)
c. Unknown
$1.3785^{\mathrm{a}}$
$1.3783^{\mathrm{a}}$
$1.3650^{\mathrm{a}}$
(.1139)
(.1136)
(.1136)

D. Characteristics of

household head

1. Race
a. White
$----$
b. Black
$.4208^{\mathrm{a}}$
$.4292^{\mathrm{a}}$
$.4801^{\mathrm{a}}$
(.1267)
(.1296)
(.1241)
c. Other
$-.2971^{\mathrm{c}}$
$-.3267^{b}$
$-.4979^{a}$
(.1653)
(.1563)
(.1721)

2. Age

\begin{tabular}{cccc} 
a. Under 25 & --- & --- & --- \\
b. $25-34$ & $-.9037^{\mathrm{a}}$ & $-.9184^{\mathrm{a}}$ & $-.9218^{\mathrm{a}}$ \\
& $(.1898)$ & $(.1889)$ & $(.1879)$ \\
c. $35-44$ & $-.7549^{\mathrm{a}}$ & $-.7684^{\mathrm{a}}$ & $-.7774^{\mathrm{a}}$ \\
& $(.1911)$ & $(.1894)$ & $(.1893)$ \\
d. $45-54$ & $-.9708^{\mathrm{a}}$ & $-.9882^{\mathrm{a}}$ & $-.9940^{\mathrm{a}}$ \\
& $(.1991)$ & $(.1976)$ & $(.1975)$ \\
e. $55-64$ & $-1.3133^{\mathrm{a}}$ & $-1.3331^{\mathrm{a}}$ & $-1.3573^{\mathrm{a}}$ \\
& $(.2134)$ & $(.2118)$ & $(.2127)$ \\
\hline f. 65 or older & $-1.7764^{\mathrm{a}}$ & $-1.7891^{\mathrm{a}}$ & $-1.818^{\mathrm{a}}$ \\
& $(.2405)$ & $(.2399)$ & $(.2415)$
\end{tabular}

3. Marital status 

a. Married
b. Divorced
$.9170^{\mathrm{a}}$
$.9169^{\mathrm{a}}$
$.8937^{\mathrm{a}}$
(.1221)
(.1217)
(.1217)
c. Separated
$.8380^{\mathrm{a}}$
$.8320^{\mathrm{a}}$
$.8544^{\mathrm{a}}$
(.1945)
(.1940)
(.1936)
d. Widowed
.1745
.1813
$.2011^{\mathrm{c}}$
(.1132)
(.1128)
(.1137)
e. Never married
$.2498^{\mathrm{b}}$
$.2474^{\mathrm{b}}$
$.2492^{\mathrm{a}}$
(.1008)
(.1014)
(.1006)
f. Unknown
$-.1969$
$-.2035$
$-.2355$
(.2677)
(.2677)
(.2668)

4. Education
a. High school dropout
b. High school graduate
$-.0559$
$-.0301$
$-.0473$
(.1103)
(.1138)
(.1147)
c. Some college
.0430
.0583
$-.0042$
(.1234)
(.1263)
(.1299)
d. College graduate
$-.2472^{b}$
$-.2246^{c}$
$-.2669^{b}$
(.1124)
(.1151)
(.1163)
e. Unknown
$-.3423^{\mathrm{c}}$
$-.3249$
$-.3458^{c}$
(.1993)
(.2003)
(.2006)

5. Work status
a. Work past 7 days
$-.2188^{b}$
$-.2162^{b}$
$-.1986^{\mathrm{a}}$
(.0857)
(.0861)
(.0859)
b. Unknown
$-.4561^{\mathrm{b}}$
$-.4548^{\mathrm{b}}$
$-.4200^{\mathrm{a}}$
(.2171)
(.2176)
(.2136)

6. Away from Home

During Evenings
a. Every night
$.3497^{\mathrm{a}}$
$.3536^{\mathrm{a}}$
$.3678^{\mathrm{a}}$
(.0884)
(.0877)
(.0869)
b. Once a week
.0308
.0358
.0393
(.0663)
(.0662)
(.0657)
c. Less than once a week
d. Unknown
$-1.1566^{\mathrm{a}}$
$-1.1542^{\mathrm{a}}$
$-1.1857$
(.2158)
(.2166)
(.2125) 
E. County Demographics

1. Percent Black

$-.0046$

(.0083)

2. Percent Hispanic

.0057

(.0044)

3. Percent in Poverty

.0146

(.0173)

4. Female Labor Force

.0167

Participation Percent

(.0241)

5. Density $(1,000$ persons

$-.0309^{b}$

per square kilometer)

(.0121)

F. Intercept

$3.0817^{\mathrm{a}}$

$2.7482^{\mathrm{a}}$

$3.200^{\mathrm{a}}$

(.3844)

(.5005)

Note: All regression specifications also included dummy variables for household income levels. Model 3 also included state fixed effects.

$\mathrm{a}=$ Statistically significant at the 1 percent level, $\mathrm{b}=$ Statistically significant at the 5 percent level, $\mathrm{c}=$ Statistically significant at the 10 percent level. 
Table 7

Effects of Gun Prevalence on Probability of Gun Theft in Burglary

Cross-Section OLS Regression Results

NCVS Data, 1994-1998

Coefficients and Standard Errors

\begin{tabular}{lcc}
\hline & $\begin{array}{c}\text { Dependent variable }=\text { gun stolen in residential burglary } \\
\text { Complete sample } \\
(\mathrm{N}=329,101)\end{array}$ & $\begin{array}{c}\text { Burglary cases only } \\
(\mathrm{N}=6,929)\end{array}$ \\
\hline Co-variates in Specification & $.00465^{\mathrm{a}}$ & $.105^{\mathrm{a}}$ \\
1. None & $(.00050)$ & $(.017)$ \\
2. Household characteristics & $.00403^{\mathrm{a}}$ & $.091^{\mathrm{a}}$ \\
& $(.00049)$ & $(.019)$ \\
3. Household characteristics and & $.00193^{\mathrm{b}}$ & $.054^{\mathrm{c}}$ \\
State fixed effects & $(.00086)$ & $(.032)$ \\
4. Household characteristics and & $.00269^{\mathrm{a}}$ & $.072^{\mathrm{a}}$ \\
county co-variates & $(.00077)$ & $(.027)$ \\
\hline
\end{tabular}

Note: Each entry is the estimated coefficient and standard error on the gun-prevalence proxy from a regression with specification and data as indicated.

$\mathrm{a}=$ Statistically significant at the 1 percent level, $\mathrm{b}=$ Statistically significant at the 5 percent level, $\mathrm{c}=$ Statistically significant at the 10 percent level. 


\section{Table 8}

\section{Specification Tests for Burglary Regressions \\ Cross-Section OLS Regression Results \\ NCVS Data, 1994-98 \\ Coefficients and Standard Errors}

\begin{tabular}{|c|c|c|c|c|}
\hline $\begin{array}{l}\text { Co-variates in } \\
\text { specification }\end{array}$ & Burglary & $\begin{array}{c}\text { Motor Vehicle } \\
\text { Theft }\end{array}$ & $\begin{array}{l}\text { Telephone in } \\
\text { Residence }\end{array}$ & $\begin{array}{c}\text { Use Public } \\
\text { Transportation }\end{array}$ \\
\hline 1. Simple & $\begin{array}{l}.0245^{\mathrm{a}} \\
(.0034)\end{array}$ & $\begin{array}{c}.0010 \\
(.0013)\end{array}$ & $\begin{array}{l}-.0450^{\mathrm{a}} \\
(.0141)\end{array}$ & $\begin{array}{l}-.733^{\mathrm{a}} \\
(.103)\end{array}$ \\
\hline $\begin{array}{l}\text { 2. Household } \\
\text { characteristics }\end{array}$ & $\begin{array}{l}.0137^{\mathrm{a}} \\
(.0030)\end{array}$ & $\begin{array}{c}.0003 \\
(.0014)\end{array}$ & $\begin{array}{l}-.0255^{\mathrm{b}} \\
(.0100)\end{array}$ & $\begin{array}{l}-.730^{\mathrm{a}} \\
(.076)\end{array}$ \\
\hline $\begin{array}{l}\text { 3. Household } \\
\text { characteristics and } \\
\text { state fixed effects }\end{array}$ & $\begin{array}{l}.0126^{\mathrm{b}} \\
(.0053)\end{array}$ & $\begin{array}{l}-.0001 \\
(.0029)\end{array}$ & $\begin{array}{l}-.0277 \\
(.0175)\end{array}$ & $\begin{array}{l}-.937^{\mathrm{a}} \\
(.112)\end{array}$ \\
\hline $\begin{array}{l}\text { 4. Household } \\
\text { characteristics and } \\
\text { county co-variates }\end{array}$ & $\begin{array}{l}.0110^{\mathrm{b}} \\
(.0043)\end{array}$ & $\begin{array}{c}.0003 \\
(.0019)\end{array}$ & $\begin{array}{c}.0040 \\
(.0130)\end{array}$ & $\begin{array}{l}-.550^{\mathrm{a}} \\
(.068)\end{array}$ \\
\hline
\end{tabular}

Note: Each entry is the estimated coefficient and standard error on the gun-prevalence proxy from a regression with specification as indicated.

$\mathrm{a}=$ Statistically significant at the 1 percent level, $\mathrm{b}=$ Statistically significant at the 5 percent level, $\mathrm{c}=$ Statistically significant at the 10 percent level. 


\section{Table 9}

\section{Effects of Gun Prevalence on Probability of Burglary \\ Two-State Least Squares Regression Results \\ NCVS Data, 1996-98 \\ Coefficients and Standard Errors}

\begin{tabular}{lcc}
\hline Co-variates in Specification & $\begin{array}{c}\text { First Stage } \\
\text { (IV on Gun Prevalence) }\end{array}$ & $\begin{array}{c}\text { Second Stage } \\
\text { (Gun Prevalence on Burglary) }\end{array}$ \\
\hline 1. None & $.5433^{\mathrm{a}}$ & $.0199^{\mathrm{c}}$ \\
& $(.0985)$ & $(.0104)$ \\
2. Household characteristics & $.5440^{\mathrm{a}}$ & .0098 \\
& $(.0591)$ & $(.0083)$ \\
3. Household characteristics & $.3503^{\mathrm{a}}$ & .0108 \\
and county co-variates & $(.0642)$ & $(.0130)$ \\
\hline
\end{tabular}

Note: Entries in the "First Stage" column are the estimated coefficients and asymptotic standard errors of the instrumental variable (\% rural in the state in 1950). Entries in the "Second Stage" are the estimated coefficients and asymptotic standard errors for gun prevalence proxy on the probability of burglary. $\mathrm{N}=192,286$.

$\mathrm{a}=$ Statistically significant at the 1 percent level, $\mathrm{b}=$ Statistically significant at the 5 percent level, $\mathrm{c}=$ Statistically significant at the 10 percent level. 
Table 10

\section{Effects of Gun Prevalence on Probability of "Hot" Burglary \\ Cross-Section OLS Regression Results \\ NCVS Data, 1994-1998 \\ Coefficients and Standard Errors}

\begin{tabular}{lcc}
\hline & $\begin{array}{c}\text { Dependent variable = gun stolen in } \\
\text { residential burglary }\end{array}$ \\
Co-variates in Specification & $\begin{array}{c}\text { Burglary cases only } \\
\mathrm{N}=6,929)\end{array}$ & $\begin{array}{c}\text { Complete sample } \\
(\mathrm{N}=329,101)\end{array}$ \\
\hline 1. None & -.0837 & $.00587^{\mathrm{a}}$ \\
& $(.0523)$ & $(.00127)$ \\
2. Household characteristics & -.0495 & $.00348^{\mathrm{a}}$ \\
3. Household characteristics and State fixed & $(.0517)$ & $(.00128)$ \\
effects & -.0625 & $.00376^{\mathrm{c}}$ \\
4. Household characteristics and county co- & $(.0909)$ & $(.00228)$ \\
variates & -.0226 & $.00339^{\mathrm{c}}$ \\
\hline
\end{tabular}

Note: Each entry is the estimated coefficient and standard error on the gun-prevalence proxy from a regression with specification and data as indicated.

$\mathrm{a}=$ Statistically significant at the 1 percent level, $\mathrm{b}=$ Statistically significant at the 5 percent level, $\mathrm{c}=$ Statistically significant at the 10 percent level. 
Table A1

Effects of Gun Prevalence on Burglary Rates

Regression Results from Repeated 36-Month Cross-Sections

UCR State-Level Data, 1977-1998

Complete List of Coefficients and Standard Errors

\begin{tabular}{|c|c|c|c|}
\hline & $\frac{\text { Outcome m }}{\Delta \text { Burg }_{\text {it }}}$ & $\Delta \log$ Burg $_{\text {it }}$ & $\Delta \log$ Burg $_{\text {it }}$ \\
\hline$\Delta \mathrm{G}_{\mathrm{it}-1}$ & $\begin{array}{l}14.6153^{b} \\
(6.7823)\end{array}$ & $\begin{array}{l}0.0015^{\mathrm{b}} \\
(0.0045)\end{array}$ & \\
\hline$\Delta \log \mathrm{G}_{\mathrm{it}-1}$ & & & $\begin{array}{l}0.6977 \\
(0.2076)^{\mathrm{b}}\end{array}$ \\
\hline$\Delta \log \mathrm{G}_{\mathrm{it}-2}$ & & & $\begin{array}{l}0.4682^{\mathrm{c}} \\
(0.2665)\end{array}$ \\
\hline$\Delta \log$ Burg $_{\mathrm{it}-1}$ & & & $\begin{array}{l}-0.3604 \\
(0.1660)^{b}\end{array}$ \\
\hline$\Delta \log$ Burg $_{\mathrm{it}-2}$ & & & $\begin{array}{l}-0.0246 \\
(0.1291)\end{array}$ \\
\hline$\Delta$ State unemp rate & $\begin{array}{l}7.6282^{c} \\
(3.8702)\end{array}$ & $\begin{array}{l}0.0064 \\
(0.0031)^{b}\end{array}$ & $\begin{array}{l}0.0014 \\
(0.0032)\end{array}$ \\
\hline $\begin{array}{l}\Delta \text { Per capita income } \\
(\$ 1,000 ' s)\end{array}$ & $\begin{array}{l}14.9466 \\
(15.2464)\end{array}$ & $\begin{array}{l}-0.0239 \\
(0.0150)\end{array}$ & $\begin{array}{l}-0.0089 \\
(0.0142)\end{array}$ \\
\hline$\Delta$ Prisoners per capita & $\begin{array}{l}-0.4338^{b} \\
(0.1259)\end{array}$ & $\begin{array}{l}-0.0003^{b} \\
(0.0001)\end{array}$ & $\begin{array}{l}-0.0005^{\mathrm{b}} \\
(0.0001)\end{array}$ \\
\hline $\begin{array}{l}\Delta \text { Alcohol consumption } \\
\text { per capita }\end{array}$ & $\begin{array}{l}15.8253 \\
(106.6787)\end{array}$ & $\begin{array}{l}0.0318 \\
(0.0614)\end{array}$ & $\begin{array}{l}0.0700 \\
(0.0705)\end{array}$ \\
\hline$\Delta \%$ poor & $\begin{array}{l}18.5883 \\
(11.7789)\end{array}$ & $\begin{array}{l}0.0102 \\
(0.0070)\end{array}$ & $\begin{array}{l}0.0103 \\
(0.0070)\end{array}$ \\
\hline$\Delta \%$ black & $\begin{array}{l}1.6348 \\
(2.9934)\end{array}$ & $\begin{array}{l}0.0017 \\
(0.0022)\end{array}$ & $\begin{array}{l}0.0025 \\
(0.0022)\end{array}$ \\
\hline $\begin{array}{l}\text { Year effects } \\
\text { included in model? }\end{array}$ & Yes & Yes & Yes \\
\hline $\begin{array}{l}\text { State fixed effects } \\
\text { included in model? }\end{array}$ & Yes & Yes & Yes \\
\hline $\begin{array}{l}\mathrm{N} \\
\mathrm{R} \text {-squared }\end{array}$ & $\begin{array}{l}253 \\
0.5863\end{array}$ & $\begin{array}{l}253 \\
0.6135\end{array}$ & $\begin{array}{l}202 \\
0.7102\end{array}$ \\
\hline
\end{tabular}

NOTES: Missing values for co-variates are set to zero with missing-data dummies included as additional controls (not shown). State population used as weights; robust standard errors presented in parentheses. $\mathrm{b}=$ Statistically significant at the 5 percent level, $\mathrm{c}=$ Statistically significant at the 10 percent level. 
Table A2

Variable Definitions

NCVS Data, 1994-1998

\begin{tabular}{|c|c|c|c|c|}
\hline Explanatory Variable & Type & Definition & Mean & $\begin{array}{l}\text { Standard } \\
\text { Deviation }\end{array}$ \\
\hline A. Gun Prevalence & $\mathrm{C}$ & $\begin{array}{l}\text { \% Gun Suicides/ } \\
\text { Total Suicides in } \\
\text { County 1987-96 }\end{array}$ & 54.08 & 12.48 \\
\hline \multicolumn{5}{|l|}{ B. Residential Characteristics } \\
\hline \multicolumn{5}{|l|}{ 1. Type of Building } \\
\hline a. 1 Unit & $\mathrm{D}$ & $\begin{array}{c}\text { Structure has } 1 \\
\text { housing unit } \\
\text { (home) }\end{array}$ & ---- & ---- \\
\hline b. 2-4 units & $\mathrm{D}$ & $\begin{array}{l}\text { Structure has 2-4 } \\
\text { housing units }\end{array}$ & .113 & .317 \\
\hline c. 5 or more units & $\mathrm{D}$ & $\begin{array}{l}\text { Structure has } 5+ \\
\text { housing units }\end{array}$ & .206 & .404 \\
\hline d. Mobile home & $\mathrm{D}$ & $\begin{array}{l}\text { Structure is mobile } \\
\text { home }\end{array}$ & .027 & .163 \\
\hline e. Other type & $\mathrm{D}$ & $\begin{array}{c}\text { Structure is of } \\
\text { other type }\end{array}$ & .014 & .116 \\
\hline \multicolumn{5}{|l|}{ 2. Location } \\
\hline a. Urban area & $\mathrm{D}$ & $\begin{array}{c}\text { Household is in } \\
\text { central city of } \\
\text { MSA }\end{array}$ & ---- & ---- \\
\hline b. Suburban area & $\mathrm{D}$ & $\begin{array}{l}\text { Household is in } \\
\text { MSA, but not in } \\
\text { central city }\end{array}$ & .593 & .491 \\
\hline c. Rural area & $\mathrm{D}$ & $\begin{array}{c}\text { Household is not in } \\
\text { MSA }\end{array}$ & .013 & .112 \\
\hline \multicolumn{5}{|l|}{ C. Household characteristics } \\
\hline 1. Male head & $\mathrm{D}$ & $\begin{array}{l}\text { Reference person } \\
\text { is male }\end{array}$ & .597 & .491 \\
\hline 2. Renter occupied & $\mathrm{D}$ & $\begin{array}{l}\text { Reference person } \\
\text { rents home }\end{array}$ & .363 & .481 \\
\hline
\end{tabular}


3. Children
a. None under 12
D No children under
12 in household
b. 1 under 12
D 1 child under 12 in
.134
.340
c. 2 or more under 12
D 2 or more children
.136
.343 under 12 in $\mathrm{HH}$
d. None or 112 or older
D 1 or no children over 12 in $\mathrm{HH}$
e. 212 or older
2 children 12 or
older in $\mathrm{HH}$
.469
.499
f. 3 or more 12 or older
D 3 or more children
.234 12 or older in $\mathrm{HH}$

4. Time at address

a. More than 2 years

D Have lived at current address more than 2 years

b. Two years or less

D Have lived at current address 2 years or less

c. Unknown

D Unknown how long lived at current address

D. Characteristics of household head

1. Race
a. White
D Reference person white (may include Hispanic)
b. Black
D Reference person black (may include Hispanic)
c. Other
D Reference person other race (may include Hispanic)




\begin{tabular}{|c|c|c|c|c|}
\hline a. Under 25 & $\mathrm{D}$ & $\begin{array}{l}\text { Reference person } \\
\text { under age } 25\end{array}$ & ---- & ---- \\
\hline b. $25-34$ & $\mathrm{D}$ & $\begin{array}{l}\text { Reference person } \\
\text { age 25-34 }\end{array}$ & .195 & .396 \\
\hline c. $35-44$ & $\mathrm{D}$ & $\begin{array}{l}\text { Reference person } \\
\text { age } 35-44\end{array}$ & .232 & .422 \\
\hline d. $45-54$ & $\mathrm{D}$ & $\begin{array}{l}\text { Reference person } \\
\text { age } 55-54\end{array}$ & .189 & .391 \\
\hline e. $55-64$ & D & $\begin{array}{l}\text { Reference person } \\
\text { age } 55-64\end{array}$ & .121 & .327 \\
\hline f. 65 or older & $\mathrm{D}$ & $\begin{array}{l}\text { Reference person } \\
\text { age } 65 \text { or older }\end{array}$ & .206 & .404 \\
\hline \multicolumn{5}{|l|}{ tal status } \\
\hline Married & $\mathrm{D}$ & $\begin{array}{l}\text { Reference person } \\
\text { married }\end{array}$ & ---- & ---- \\
\hline Divorced & $\mathrm{D}$ & $\begin{array}{l}\text { Reference person } \\
\text { divorced }\end{array}$ & .113 & .317 \\
\hline Separated & D & $\begin{array}{c}\text { Reference person } \\
\text { separated }\end{array}$ & .027 & .163 \\
\hline Widowed & D & $\begin{array}{l}\text { Reference person } \\
\text { widowed }\end{array}$ & .099 & .298 \\
\hline Never married & D & $\begin{array}{l}\text { Reference person } \\
\text { never married }\end{array}$ & .136 & .342 \\
\hline Unknown & $\mathrm{D}$ & $\begin{array}{l}\text { Reference person } \\
\text { marital status } \\
\text { unknown }\end{array}$ & .006 & .074 \\
\hline
\end{tabular}

4. Education

a. High school dropout

D Reference person a high school dropout

b. High school graduate
D Reference person a $\quad .300$ high school graduate

c. Some college
D Reference person attended some college



d. College graduate
D Reference person a
.285
e. Unknown
D Reference person
.016
educational status unknown

.452

5. Work status
a. Work past 7 days

D

Has reference

.613

.487 person been employed in past week?

b. Unknown
D Reference person work status unknown

.070

6. Away from Home

During Evenings
a. Every night
D Reference person away from home every night of week?
.175
.380
b. Once a week
D Reference person away from home one night a week?
c. Less than once a week
D Reference person away from home under one night a week?
d. Unknown
D Reference person
.073 .260 away from home
information
unknown

E. County Demographics

1. Percent Black

2. Percent Hispanic
C Percent black in county, 1990

C Percent Hispanic in county, 1990

3. Percent in Poverty

11.38 5.03 in county, 1990 


\begin{tabular}{|c|c|c|c|c|}
\hline $\begin{array}{l}\text { 4. Female Labor Force } \\
\text { Participation Percent }\end{array}$ & $\mathrm{C}$ & $\begin{array}{l}\text { Percent of female } \\
\text { population in labor } \\
\text { force in county, } \\
1990\end{array}$ & 16.78 & 5.23 \\
\hline 5. Density & $\mathrm{C}$ & $\begin{array}{l}\text { Number of people } \\
\text { (in 1,000s) per } \\
\text { square km in } \\
\text { county, } 1990\end{array}$ & .780 & 2.111 \\
\hline \multicolumn{5}{|l|}{ F. Dependent Variables } \\
\hline 1. Burglary & $\mathrm{D}$ & $\begin{array}{l}\text { Household } \\
\text { burglary in } \\
\text { previous } 6 \\
\text { months? }\end{array}$ & .019 & .135 \\
\hline 2. Hot & $\mathrm{D}$ & $\begin{array}{l}\text { Was someone at } \\
\text { home during a } \\
\text { burglary in } \\
\text { previous } 6 \\
\text { months? }\end{array}$ & .005 & .074 \\
\hline 3. Gun Stolen & $\mathrm{D}$ & $\begin{array}{l}\text { Was a gun stolen } \\
\text { from household in } \\
\text { previous } 6 \\
\text { months? }\end{array}$ & .001 & .031 \\
\hline 4. Phone & $\mathrm{D}$ & $\begin{array}{l}\text { Does household } \\
\text { have a phone? }\end{array}$ & .963 & .190 \\
\hline 5. Public Transportation & $\mathrm{D}$ & $\begin{array}{l}\text { Does reference } \\
\text { person use public } \\
\text { transportation? }\end{array}$ & .279 & .448 \\
\hline 6. Motor Vehicle Theft & $\mathrm{D}$ & $\begin{array}{l}\text { Household motor } \\
\text { vehicle theft in } \\
\text { previous } 6 \\
\text { months? }\end{array}$ & .003 & .053 \\
\hline 7. Larceny & $\mathrm{D}$ & $\begin{array}{c}\text { Household larceny } \\
\text { in previous } 6 \\
\text { months? }\end{array}$ & .092 & .289 \\
\hline
\end{tabular}

Notes: Reference person is NCVS term for head of household. Variable types D-Dummy (0,1), C-Continuous. N=329,102 


\section{APPENDIX B Assessing the Likely Direction of Error in the IV Estimates}

In this appendix we outline the argument for why any bias in our instrumental variables (IV) estimates introduced by correlation between our instrument and the unobserved determinants of burglary rates is likely to lead us to overstate deterrence and understate inducement effects.

In equations (B1) and (B2) we reproduce the first and second stage equations that we use

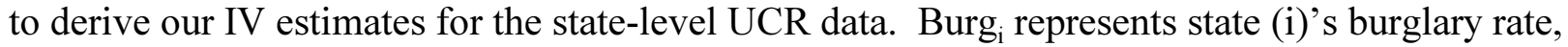
$\mathrm{G}_{\mathrm{i}}$ is the gun-prevalence proxy, $\mathrm{e}_{\mathrm{i}}$ is a stochastic error term and $\mathrm{R}_{\mathrm{i}}$ represents the proportion of the state that lived in rural areas in 1950. We use two-stage least squares to estimate a predicted value of the gun index in the first-stage equation (B1) as a function of the instrumental variable, the proportion of the state living in rural areas in 1950; the predicted value for the gun index from this first-stage equation is then substituted for the actual value in the second stage equation (B2). Note that the actual equations that we estimate also include a common set of exogenous control variables $\mathrm{X}_{\mathrm{i}}$ and intercept terms. Because the inclusion of co-variates does not change the analysis (Bound, Jaeger and Baker, 1995), we exclude co-variates from the equations to simplify the discussion. We also note that the county-level UCR analysis and household-level NCVS estimates are calculated using the same set of equations, with $\mathrm{R}_{\mathrm{i}}$ measured at the state level, $\mathrm{G}_{\mathrm{i}}$ measured at the county level and the second-stage standard errors adjusted accordingly.

$$
\begin{aligned}
& \mathrm{G}_{\mathrm{i}}=\alpha \mathrm{R}_{\mathrm{i}}+\mathrm{v}_{\mathrm{i}} \\
& \operatorname{Burg}_{\mathrm{i}}=\theta \mathrm{G}_{\mathrm{i}}+\mathrm{e}_{\mathrm{i}}
\end{aligned}
$$

Bound, Jaeger and Baker (1995) show that in this set-up the bias of the instrumental variables estimate for $\theta$ is given by equation (B3), where $\sigma^{2}$ represents the variance of the gun index variable and $\sigma_{\Gamma, \mathrm{e}}$ represents the covariance between the predicted value of the gun index from the first stage equation, $\Gamma$, and the second stage error term, e.

$$
\operatorname{plim} \theta_{\mathrm{IV}}-\theta=\sigma_{\Gamma, \mathrm{e}} / \sigma_{\mathrm{G}}^{2}
$$

Our argument that this bias is likely to overstate the deterrent effect of guns on burglaries stems from the fact that areas that were more rural in 1950 have higher gun ownership rates $(\alpha>0)$, as shown in Table 5, and that areas that are currently more rural have if anything lower burglary rates than urban communities. This second observation comes from cross-section analysis of the NCVS, which suggests that households outside of metropolitan statistical areas (MSA's) clearly have lower burglary rates than other respondents even after conditioning on the rich set of household characteristics described in the text. We similarly find in the UCR that states in which a larger proportion of residents currently live in MSA's have relatively higher burglary rates. These findings suggest that the covariance between the instrument and the second-stage error term, $\sigma_{\mathrm{R}, \mathrm{e}}$, is negative. If $\alpha>0$ and $\sigma_{\mathrm{R}, \mathrm{e}}<0$ then $\sigma_{\Gamma, \mathrm{e}}<0$ and, because $\sigma_{\mathrm{G}}^{2}>0$, the IV estimate will be biased in the direction of overstating the deterrent effect from guns. 